\title{
Climate change impact on a wine-producing region using a dynamical downscaling approach: Climate parameters, bioclimatic indices and extreme indices
}

\author{
Daniel Blanco-Ward ${ }^{1}$ (i) । Alexandra Monteiro' ${ }^{1}$ Myriam Lopes $^{1}$ | Carlos Borrego ${ }^{1}$ | \\ Carlos Silveira $^{1}$ | Carolina Viceto ${ }^{2}$ (i) I Alfredo Rocha ${ }^{2}$ | António Ribeiro ${ }^{3}$ | \\ João Andrade $^{3}$ | Manuel Feliciano ${ }^{3}$ ， João Castro ${ }^{3}$ ～David Barreales ${ }^{3}$ | Jorge Neto J $^{4}$ \\ Cristina Carlos $^{5}$ | Carlos Peixoto6 | Ana Miranda ${ }^{1}$
}

${ }^{1}$ Department of Environment and Planning (DAO) \& Centre for Environmental and Marine Studies (CESAM), Aveiro University, Aveiro, Portugal

${ }^{2}$ Physics Department \& CESAM, Aveiro University, Aveiro, Portugal

${ }^{3}$ Mountain Research Centre (CIMO), Instituto Politécnico de Bragança, Campus de Santa Apolónia, Bragança, Portugal

${ }^{4}$ Portuguese Institute for the Sea and the Atmosphere (IPMA), Climate and Climate Change Division, Rua C ao Aeroporto, Lisbon, Portugal

${ }^{5}$ Association for the Development of Viticulture in the Douro Region (ADVID), Edificío Centro de Excelência da Vinha e do Vinho - Régia Douro Park, Vila Real, Portugal

${ }^{6}$ Casa Ramos Pinto, Vila Nova de Foz Côa, Portugal

\section{Correspondence}

Daniel Blanco-Ward, Department of Environment and Planning (DAO), Aveiro University, Campus Universitário de Santiago, 3810-193 Aveiro, Portugal. Email: dblancoward@ua.pt

Funding information Fundação para a Ciência e a Tecnologia, Grant/Award Numbers: PTDC/AAGMAA/3335/2014; POCI-01-0145-FEDER016778, SFRH/BD/139193/2018

\begin{abstract}
Climate change is of major relevance to wine production as most of the winegrowing regions of the world are located within relatively narrow latitudinal bands with average growing-season temperatures (GSTs) limited to $13-21^{\circ} \mathrm{C}$. This study focuses on the incidence of climate variables and indices that are relevant both for climate change assessment and for grape production, with emphasis on grapevine bioclimatic indices and extreme events (e.g., cold waves, storms, heatwaves). Dynamical downscaling of European Reanalysis-Interim and Max Planck Institute Earth System low-resolution global simulations forced with a Representative Concentration Pathway 8.5 (RCP8.5) greenhouse gas emission scenario was performed with the Weather Research and Forecast (WRF) model to a regional scale including the Douro Valley of Portugal for recent-past (1986-2005) and future periods (2046-2065, 2081-2100). The number, duration and intensity of events were superimposed over critical phenological phases estimated by using a specific local grapevine varietal phenological model in order to assess their positive or negative implications for wine production in the region. An assessment of the relevance of climate parameters and indices and their progression in recent-past and future climate scenarios with regard to the potential impact on wine production was performed. Results indicate a positive relation between higher growing-season heat accumulations and greater vintage yields. A moderate incidence of very hot days (daily maximum temperature above $35^{\circ} \mathrm{C}$ ) and drought from pre-véraison phenological conditions have a positive association with vintage ratings. However, the mid- and long-term WRF-MPI RCP8.5 future climate scenarios reveal shifts to warmer and drier conditions, with the mean GST not remaining within range for quality wine production in the long-term future climate scenario. These results indicate potential impacts that suggest a range of strategies to maintain wine production and quality in the region.
\end{abstract}




\section{KE Y W O R D S}

agrometeorology, bioclimatic indices, climate change modelling, extreme climate indices, grapevine phenology, regional and mesoscale modelling, wine production

\section{1 | INTRODUCTION}

There is a general acceptance by the scientific community of the contribution of anthropogenic greenhouse gas (GHG) emissions to climate change. Depending on the GHG emissions scenario, an increase in global mean surface temperature ranging from 1 to $3.7^{\circ} \mathrm{C}$ is expected by the end of the century when compared with the reference period 1986-2005 (IPCC, 2014). These annual temperature increases along with higher atmospheric carbon dioxide $\left(\mathrm{CO}_{2}\right)$ may lead to longer growth seasons in Northern, Central and Eastern Europe, increasing the suitability of these areas for crops now prevalent in Southern Europe such as maize or sunflower. In an opposite way, productivity and suitability for energy crops and cereals is likely to decrease in Mediterranean Southern and South-Eastern Europe due to warmer and drier climate conditions (Falloon and Betts, 2009).

The influence of climate is also critical in viticulture and wine production (Jones et al., 2005; Van Leeuwen and Darriet, 2016; Pons et al., 2017). Year-to-year meteorological variations affect the yield and optimal environmental conditions for grapes to ripen and, therefore, whether wine typicity for a given "terroir" or grapevine-growing region will be correctly expressed to achieve its full potential. This influence is known as the "vintage effect", with climate having a greater impact on yield and quality than other environmental factors such as soil type or grapevine variety. In this sense, it is already known that an increase of temperature produces an advance in phenology, which in turn could have advantageous effects in northern or Atlantic conditions but be detrimental under Mediterranean conditions (Moriondo et al., 2013; Fraga et al., 2016). As the grapes are exposed to higher temperatures due both to climate change and advanced phenology, the supply of metabolites to the grapes is altered, generally causing greater sugar accumulation and higher alcohol levels, lower acidity and variable effects on different aromas and secondary metabolites (Mira de Orduña, 2010; Teixeira et al., 2013).

Jones and Alves (2012) also emphasized that most of the wine-growing regions of the world, in particular the Douro region in Portugal, are located within relatively narrow latitudinal bands with average April to October growing-season temperatures (GSTs) limited to $13-21^{\circ} \mathrm{C}$. Therefore, small changes in temperature could affect the typicity and style of the wine produced, and if a climatic threshold is exceeded, balanced grape ripening becomes impaired.

The multicriteria climatic classification (MCC) system for grape-growing regions worldwide (Tonietto and Carbonneau, 2004) along with other bioclimatic indices (e.g., Winkler index [WI], Branas hydrothermic index) have been commonly used to assess the impact of climate change on the suitability for wine production across Europe. For instance, Malheiro et al. (2010) calculated the indices from climate variables obtained from simulations with a $0.165^{\circ}$ latitude-longitude resolution (grid size of about $18 \mathrm{~km}$ ) performed with the regional climate model COSMO-CLM for the recent-past climate (1960-2000) and for the 21st century (2011-2040, 2041-2070 and 2071-2100 time periods). Their results indicated an increased soil water deficit and cumulative thermal effects during the growing season in Southern Europe, which could imply detrimental future conditions for wine production for this area unless suitable adaptation measures (e.g., rootstock and variety selection, training system and irrigation) are taken. In contrast, Western and Central Europe could benefit, with higher quality potential for grapes and even new potential areas for wine production.

In another study by Fraga et al. (2014), the atmospheric variables taken from coupled global climate-regional climate model (GCM-RCM) simulations in combination with the MCC system were used to assess present and future scenarios for the Portuguese grapevine-growing regions. An ensemble of 13 RCM simulations driven by three different GCMs produced by the ENSEMBLES project (van der Linden and Mitchell, 2009) was selected. The results illustrated relevant changes in the current bioclimatic Portuguese viticultural zones as they depict less bioclimatic diversity and a more homogenous warm and dry climate for most Portuguese wine regions.

Concerning particular studies for the Portuguese Douro Valley region, a multivariate linear regression analysis was performed by Santos et al. (2013) relating a long wineproduction series (1932-2010) collected by the Instituto dos Vinhos do Douro e Porto (IVDP), and atmospheric variables (namely, temperature and precipitation) from a climatological station available for the period 1941-2010. Results indicated that high rainfall and cool temperatures during budburst, shoot and inflorescence development (February- 
March) and warm temperatures during flowering and berry development (May) are generally favourable for high production. The regression approach was then applied to climate parameters computed from atmospheric variables provided by $16 \mathrm{RCM}$ experiments for recent-past and future climate changes for the period 2001-2099. An overall positive impact was found, with an increase of $10 \%$ in production by the end of the 21st century and an increase of high-production years from 25 to over $60 \%$. Corte-Real et al. $(2015 ; 2016)$ developed another statistical work relating wine production to climate in the Portuguese Douro Demarcated Region (DDR). Series of climate parameters and bioclimatic indices derived from weather stations from the Portuguese National Meteorological Service present in the Douro Valley area were correlated with yield and Port wine vintage chart records used as a proxy for vintage quality. Temperature was introduced into the logistic model as the successive time periods required to reach a given threshold of heat accumulation to pass from a given grapevine phenological phase (e.g., budburst) to the next one (e.g., flowering). The results of this study illustrated that weather characteristics (e.g., GSTs above the mean, warm winters, cool temperatures during ripening) are strongly associated with better quality vintages.

Most recently, a grape production model has been developed by Fraga and Santos (2017), relating daily historic temperature and precipitation from the E-OBS observational data set with the grape production of three wineries within the Douro Valley region. The model compared ther$\mathrm{mal} /$ hydric conditions each year with the average conditions for high- and low-yield vintages. Results indicated that relatively cool pre-flowering temperatures and relatively warm conditions during berry development favour higher yields. Higher production is also associated with years with precipitation above the mean before the flowering stage.

The present research aims to advance the current state of the art by using a dynamically downscaled GCM-RCM atmospheric modelling configuration. Based on the Representative Concentration Pathway (RCP) 8.5 emission scenario (IPCC, 2008), simulations were performed for 20-year periods as adopted by the IPCC 5th Assessment Report (IPCC, 2013), namely 1986-2005 for the recent past, 2046-2065 for the mid-future and 2081-2100 for the longterm future climate. The study first aims to find significant associations between climate and key vintage production characteristics such as yield and quality in the DDR for the recent-past period using many of the pertinent climate extreme indices defined by the Expert Team on Climate Change Detection and Indices (ETCCDI) (Sillmann et al., 2013a; 2013b) besides the already commonly used atmospheric variables and the MCC system. It does so by using both a conventional approach based on Julian calendar dates and a phenological one based on thermal timings. Estimates of pertinent climate parameters and indices for both yield and vintage rating charts in the DDR as found in the first stage of this research are made thereafter for mid-term and long-term future climate scenarios. Therefore, this study offers a comprehensive analysis of 204 variables using stateof-the-art dynamically downscaled GCM-RCM high 9- and $1-\mathrm{km}$ horizontal resolution climate simulations considering recent-past and future climate scenarios including key information for the DDR wine-producing area. According to the MCC system, the study area is currently representative of climatological conditions found in other renowned Mediterranean grape-growing regions such as the Napa Valley (United States), Mildura wine district (Australia) or Lujan de Cuyo (Argentina), making this study relevant for other areas besides the Portuguese DDR.

\section{2 | STUDY AREA}

The Portuguese DDR is well known for the production of Port wine, a fortified type of wine with a long tradition produced only in Portugal and considered as one of the best wines in the world (Corte-Real et al., 2015; Fraga et al., 2017). The DDR runs along both margins of the Douro River from its midcourse in the west up to the border with Spain in the east. It extends along $50 \mathrm{~km}$ in the north-south direction and along $90 \mathrm{~km}$ in the west-east direction, with the westernmost area located $70 \mathrm{~km}$ from the Atlantic Ocean. The landscape is characterized by mountainous terrain, rising above the Douro River and its tributaries, with moderate to steep slopes and varying exposures. The average elevation over the entire region is $443 \mathrm{~m}$, but it ranges from a low near $40 \mathrm{~m}$ to a high of just over 1,400 $\mathrm{m}$ (Jones, 2013). The location of the study area is shown in Figure 1.

The region covers approximately 250,000 ha, with sloping vineyard areas representing roughly 43,480 ha (17.4\% of the total land area) arranged in various terraced configurations. As observed in Figure 1, the DDR is divided into three subregions: Baixo Corgo, Cima Corgo and Douro Superior. Baixo Corgo covers the smallest area (45,000 ha), with Cima Corgo the next largest (95,000 ha) and Douro Superior the largest subregion $(110,000 \mathrm{ha})$. The vineyard figures for these subregions are 13,368, 20,270 and 9,842 ha, respectively (IVDP, 2017a).

The DDR has a Mediterranean climate, with highly variable rainfall events concentrated in winter months, and hot summers. It is sheltered from Atlantic wet and cold winds by two mountain ranges, Marão and Montemuro, located at its western border. Temperature increases, and precipitation decreases from west to east. The westernmost subregion inside the Douro Valley (Baixo Corgo) is nearer to the Atlantic Ocean and therefore more affected by the moist 


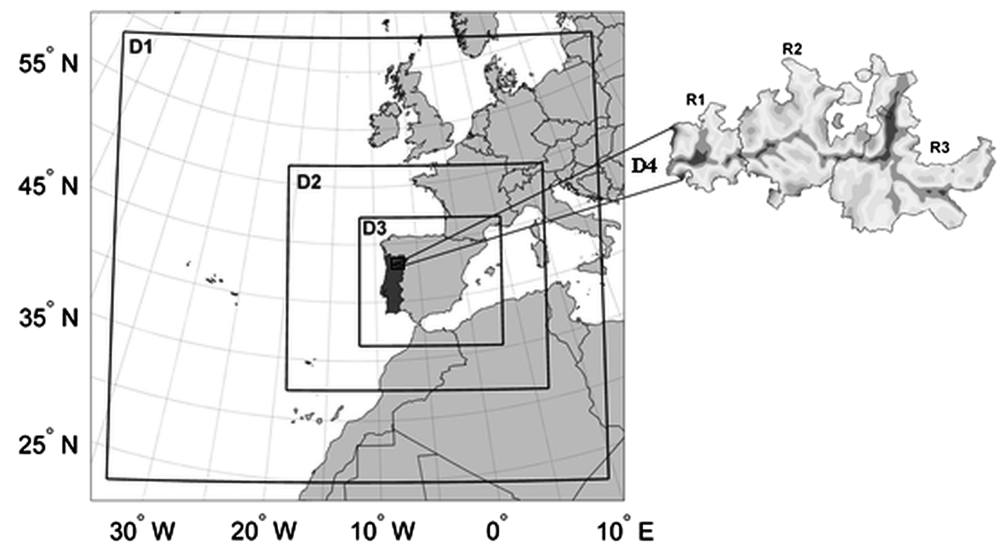

FIGURE 1 Map of the Douro demarcated region in Portugal. The map shows the location of the subregions "Baixo Corgo" (R1), "Cima Corgo" (R2) and "Douro superior" (R3). Nested domains used in the regional WRF model implementation are shown as squares. The domains have increasing horizontal resolution: 81 (D1), 27 (D2), 9 (D3) and $1 \mathrm{~km}$ (D4) maritime winds. The easternmost regions within the Douro Superior subarea are more distant from the Atlantic Ocean, therefore having a more continental climate influence. According to Corte-Real (2014) and Corte-Real et al. (2016), the region is classified as having a warm temperate climate (cool summer type b Mediterranean climate [Csb] under the Köppen climate classification system), with average annual temperatures during $1980-2009$ of $15.4^{\circ} \mathrm{C}$, average daily minimum temperatures $\left(T_{\min }\right)$ in the coldest month (January) dropping to $2.7^{\circ} \mathrm{C}$, and average daily maximum temperatures $\left(T_{\max }\right)$ in the warmest month (August) reaching $32.1^{\circ} \mathrm{C}$. Mean GST from April to September for the same climatological period is $20.6^{\circ} \mathrm{C}$. Growing-season precipitation (GSP) from April to September has a mean value of $193 \mathrm{~mm}$, representing 30\% of the annual total $(624 \mathrm{~mm})$. The average precipitation of the driest month (July) is just $11.2 \mathrm{~mm}$. Jones and Alves (2012) emphasized that low precipitation values along with high temperatures and high radiation exposure give rise to situations of intense summer plant-soil-water stress, particularly in the Cima Corgo and Douro Superior subregions.

Based on data from three climatological stations representative of the three DDR subregions for the 1980-2009 period, the Huglin index (HI) averaged 2,740 units whereas the cool night index $(C I)$ was $13.6^{\circ} \mathrm{C}$ and the dryness index $(D I)$ was $-126 \mathrm{~mm}$. In the MCC system, the DDR climate is then classified as $\mathrm{HI}+2 / D I+2 / C I+1$ (warm/very dry/cool nights) (Corte-Real, 2014). According to Tonietto and Carbonneau (2004), other renowned Mediterranean grapegrowing regions falling under this classification are the Napa Valley (US) and the Mildura wine district (Australia). Although the MCC system is generally accepted as a useful tool to describe the climate of grape-growing regions globally, it is advisable to keep in mind that considerable variations at the mesoscale due to different factors such as topography or distance to the sea can exist (Blanco-Ward et al., 2007). In fact, values given for the Régua station within the Baixo Corgo subregion during 1951-1980, as reported by Climaco et al. (2012), were 2,489 Huglin units - close to the HI+1 2,400 HI upper limit of the temperatewarm class; $37 \mathrm{~mm}$ for DI -belonging to the DI +1 or moderately dry class; and $12.8^{\circ} \mathrm{C}$ for $\mathrm{CI}$ - falling inside the same $\mathrm{CI}+1$ category as the overall more recent classification. Those conditions would find an international match in the Lujan de Cuyo DO within the Mendoza province (Argentina). Regarding the grapevine varieties present in the DDR, Corte-Real (2014) mentioned that up to 50 are allowed by law and may be present in Port wine. Some of the most frequently used are "Touriga Nacional", "Touriga Francesa", "Tinta Roriz" ("Tempranillo"), "Tinta Barroca" and "Tinto Cão".

\section{3 | DATA AND METHODS}

In this section, the data sets and methods used in this study are described. There are two main atmospheric data sets used in this work: the Weather Research and Forecast European Reanalysis (WRF-ERA) data set comprising daily records of atmospheric variables for the 1986-2005 recent-past climate simulation, and the Weather Research and Forecast Max Planck Institute (WRF-MPI) data set also containing the 1986-2005 recent-past time span but also extending to the 2046-2065 mid-future and 2081-2100 long-term future climate scenarios. First, the WRF-ERA for the 1986-2005 recent-past simulations was validated using both a Julian calendar approach and a phenological thermal timing modelling approach. Once validated, the WRF-ERA data set was used to estimate a group of 204 climate parameters and indices relevant for wine production in the DDR by using both the Julian calendar-based approach and the phenological approach. A statistical analysis was performed thereafter in order to find significant relations between the previously estimated climate parameters and indices and vintage yield and Port wine vintage rating records for the 1986-2005 recent-past simulation. Finally, a selected subset of indices and parameters found through the previous analysis was used to validate the WRF-MPI data sets and assess the 
possible impacts of climate change under the RCP8.5 GHG emission scenario for wine production in the DDR. Figure 2 displays a summary of the workflow followed in this research.

\section{1 | High-resolution WRF climate simulations}

Two sets of GCM results were used to provide initial and boundary conditions for regional climate simulation, specifically the ERA-Interim reanalysis and the Max Planck Institute Earth System low-resolution model (MPI-ESM-LR). The reanalysis data were obtained from the European Centre for Medium-Range Weather Forecasts (ECMWF) through the ERA-Interim project, with a horizontal resolution of approximately $79 \mathrm{~km}$ (Dee et al., 2011). The MPI-ESM-LR is a global earth system model developed by the MPI with $1.9^{\circ}$ horizontal resolution which corresponds to about $160 \mathrm{~km}$ horizontal resolution (Giorgetta et al., 2013). This model participated in the Coupled Model Intercomparison Project Phase 5 (CMIP5), which uses new emission scenarios, namely the RCPs (Andrews et al., 2012). In this study, $\mathrm{RCP} 8.5$, defined as a radiative forcing of $8.5 \mathrm{~W} / \mathrm{m}^{2}$ by 2100 and a continuous increase after this year (IPCC, 2008), was used. According to Riahi et al. (2011), the RCP8.5 provides

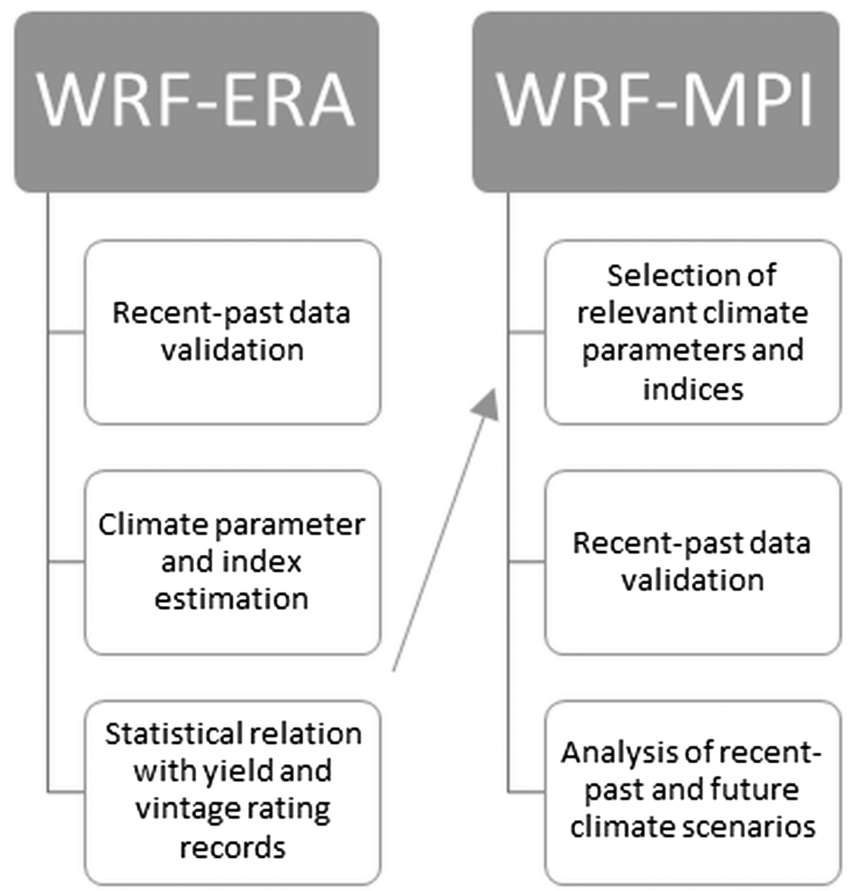

FIG URE 2 Summary of the workflow followed in this study. First, work was performed to validate the WRFERA recent-past data set. A correlation analysis was applied between climate parameters and indices and vintage yield and quality records in the DDR afterwards. Finally, the work progressed to analyse the WRFMPI recent-past, midterm and long-term future data sets based on a selection of relevant climate parameters and indices found in the previous stage an updated and revised quantification of the original IPCC A2 SRES scenario, representing a high business-as-usual GHG emission scenario assuming slow rates of economic development and technological change, and a rapidly growing population with associated high demand for food and corresponding high demand for fossil fuels. Compared with the total set of RCPs, it represents the highest GHG emissions scenario.

The WRF model was used as a dynamical downscaling tool to obtain regional climate information from the GCM simulations. WRF is a mesoscale numerical weather prediction system which can be used in a wide range of applications across scales ranging from tens to thousands of kilometres. A detailed description of the model can be found in Skamarock et al. (2008), and further information on parameterizations specifically suited for the Iberian Peninsula can be found in Marta-Almeida et al. (2016). The RCM WRF high-resolution climate simulations were performed for 20-year periods as adopted by the IPCC 5th Assessment Report (IPCC, 2013), namely 1986-2005 for the recent past, 2046-2065 for the mid-future and 2081-2100 for the longterm future climate. These simulations were implemented by Viceto et al. (2017) for three nested domains with increasing horizontal resolution, namely 81 (D1), 27 (D2) and 9 km (D3). A fourth 1-km horizontal resolution domain (D4) was implemented for 3 years only (2000, 2049 and 2097) due to the intensive computer resources required by the dynamical downscaling WRF-MPI configuration (Figure 1). This study uses the 9- and 1-km horizontal resolution domains focusing on a confined area comprising the DDR, taking advantage of the WRF dynamical downscaling approach to include the effects of proximity to the Atlantic Ocean and the complex topography of the Douro Valley in the regional climate simulations.

\section{2 | Phenological modelling}

It was Réaumur who first introduced in 1735 the concept of heat units or "thermal time" and a relationship between the development rate of a crop and temperature as a sum of heat degrees (Mcmaster and Wilhelm, 1997; Bonhomme, 2000). Heat units are nowadays commonly measured as growing degree days (GDD, ${ }^{\circ} \mathrm{C}$ units) which are estimated as a daily temperature summation above a temperature base required for a given crop to complete a specific phenological stage:

$$
\theta=\int(T-T b) d t
$$

where $\theta\left({ }^{\circ} \mathrm{C}\right)$ represents the thermal duration of a specific phenological stage, $T$ is the daily average temperature and $T b$ is a threshold above which there is plant development 
within that phenological stage. Models based on GDD have been used extensively to simulate the phenology of the grapevine (Hidalgo, 1980; Carbonneau et al., 1992) or as grapevine zoning bioclimatic indices (Winkler et al., 1974; Huglin, 1986; Riou, 1994).

A specific phenological scheme partitioning the annual development cycle of the grapevine into three major phases ( $b$ - budburst to flowering, $f$ - flowering to véraison, and $v-$ véraison to maturity) has been already proposed for the study area by Corte-Real et al. $(2015 ; 2016)$. This phenological model used a mixed grapevine variety configuration as the Tinta Roriz variety was used to define the required GDD to reach budburst, flowering and véraison, and the Touriga Franca variety was used to estimate the required GDD to reach maturity in the DDR. This was done in order to simulate an intermediate varietal behaviour (neither an early nor a late grapevine variety class) for all those phenological stages, using two varieties present extensively in the Douro Valley region.

This work makes use of the mixed "Tinta Roriz-Touriga Franca" local grapevine varietal phenological model to compute the timings of the key grapevine phenological timings ( $b$-budburst, $f$ - flowering and $v$-véraison or ripening onset) for the four climate-modelling configurations presented in Section 3.1 (WRF-ERA recent past, WRF-MPI recent past, WRF-MPI mid-future and WRF-MPI long-term future) based on the specific varietal GDD requirements as observed at the Portuguese National Ampelographic Collection (Lopes et al., 2008). In Section 4, results are compared with specific phenological observations made available for the Douro Valley region more recently (Alves et al., 2013).

\section{3 | Climate parameters and indices}

Using the daily maximum and minimum temperatures and the daily total precipitation from the four different regional WRF modelling configurations (WRF-ERA recent past, WRF-MPI recent past, WRF-MPI mid-future and WRF-MPI long-term future), a total of 50 climate parameters, four grapevine bioclimatic indices and 150 climate extreme indices were calculated.

\subsection{1 | Climate parameters}

The climate parameters resulted from computing the average of daily maximum temperatures, daily minimum temperatures and daily mean temperatures (as $T_{\max }+T_{\min } / 2$ ), the total precipitation $(P)$ for every month from April to September, and each one of the yearly phenological stages based on the conventional monthly scheme for the Northern Hemisphere (budburst usually occurs between March and April, flowering occurs more often in June and July, and véraison usually happens between August and September). Therefore, a set of 36 climatic parameters was calculated following the conventional Julian calendar scheme (e.g., $T_{\max }$ Apr-May, $T_{\min }$ Apr-May, $T_{\text {ave }}$ Apr-May, P Apr-May and so on). Another set of 12 climatic parameters was computed considering the thermal timings according to the phenological modelling ( $T_{\text {max-b }}, T_{\text {min-b }}, T_{\text {ave-b }}$, P-b and so on). Finally, two other climatic parameters were computed following the conventional scheme (months from April to October) to summarize information for intercomparison purposes: the GST and the GSP.

\subsection{2 | Bioclimatic indices}

Four specific grapevine bioclimatic indices were selected: the WI, HI, CI and DI. These indices are commonly used to characterize grapevine-growing areas worldwide in a standardized way and as an agronomic zoning tool (Tonietto and Carbonneau, 2004; Blanco-Ward et al., 2007; Jones et al., 2010; Anderson et al., 2012).

WI is the sum of the daily average temperatures above a threshold temperature of $10^{\circ} \mathrm{C}$ considered the active grapevine temperature (the temperature above which its vegetative cycle is activated) during the growing season. This index is usually calculated from monthly data taking as growing season the months between April and October (Winkler et al., 1974):

$$
\begin{aligned}
\mathrm{WI} & =\sum_{\text {April } 1 \mathrm{st}}^{\text {October } 31 \mathrm{st}}\left(T_{\mathrm{ave}}-10^{\circ} \mathrm{C}\right), T_{\mathrm{ave}} \geq 10^{\circ} \mathrm{C} \\
T_{\mathrm{ave}} & =\frac{T_{\max }+T_{\min }}{2} .
\end{aligned}
$$

The HI provides information regarding heliothermal potential. According to Tonietto and Carbonneau (2004), this index is very much correlated with WI $\left(r^{2}=0.98\right.$ over 97 grape-growing regions worldwide) but provides a better idea of qualitative factors such as berry sugar potential.

$$
\begin{aligned}
& \mathrm{HI}=\sum_{\text {April 1st }}^{\text {September } 30 \mathrm{th}} \frac{\left(T_{\max }-10^{\circ} \mathrm{C}\right)+\left(T_{\text {ave }}-10^{\circ} \mathrm{C}\right)}{2} d \\
& T_{\text {ave }}=\frac{T_{\text {max }}+T_{\text {min }}}{2},
\end{aligned}
$$

where, again, $T_{\text {ave }}$ is the mean air temperature $\left({ }^{\circ} \mathrm{C}\right), T_{\max }$ is the maximum air temperature $\left({ }^{\circ} \mathrm{C}\right)$ and $d$ is a length of day coefficient ranging from 1.02 to 1.06 between $40^{\circ}$ and $50^{\circ}$ of latitude. A value of 1.02 was assumed for a latitude between $40^{\circ} 01^{\prime}$ and $42^{\circ} 00^{\prime}$. This index is usually calculated from monthly climatic means, taking as growing season the April to September period. 
The purpose of $\mathrm{CI}$ is to improve the assessment of grape qualitative potential, notably in relation to secondary metabolites (polyphenols, aromas) in grapes, and takes into account the minimum night temperatures during the usual ripening month (Tonietto and Carbonneau, 2004).

$$
\mathrm{CI}=\sum_{\text {September } 1 \mathrm{st}}^{\text {September }} \frac{30 \mathrm{st}}{T_{\text {min }}} .
$$

Finally, DI indicates the potential water availability in the soil, related to the level of dryness in a region. It is also related to the level of grape ripening and wine quality:

$$
W=W_{o}+P-T_{v}-E_{S},
$$

where $W$ is the estimated soil water reserve at the end of a given month, $W_{0}$ is the initial soil water reserve which can be accessed by the vine roots in that period, $P$ is the total monthly precipitation, $T_{v}$ the potential transpiration of the vineyard, and $E_{s}$ the direct evaporation from the soil. To compute $T_{v}$ and $E_{s}$, it is also necessary to compute the monthly total potential evapotranspiration. This is usually done by the Penman-Monteith method but, as we only work with temperature and precipitation records, it was approximated by the Hargreaves method, which produces comparable results in arid and semiarid environments (Hargreaves et al., 2003). For intercomparison reasons, $W$ is also calculated sequentially on a monthly basis during the same period used for HI (April 1 to September 30), which is acceptable for most grape-growing regions in the Northern Hemisphere. The result is expressed in millimetres of water in the soil. The initial $W_{0}$ is usually taken as $200 \mathrm{~mm}$ (Tonietto and Carbonneau, 2004). The classes of viticultural climate for the grapevine mean GST, the WI, the Huglin index, the cool night index and the dryness index can be found in Table S1.

\subsection{3 | Extreme climate indices}

A group of 15 climate extreme indices from the group of 27 core indices developed by ETCCDI (Sillmann et al., 2013a; 2013b) related to the incidence of cold waves, storms and heatwaves, which could be relevant for the grapevine, were calculated on a yearly basis first. Namely, these indices were:

FD0, the number of frost days per year where $T_{\min }<0^{\circ} \mathrm{C}$.

SU25, the number of summer days per year where $T_{\max }>25^{\circ} \mathrm{C}$.

SU35, the number of very hot or stressful days per year where $T_{\max }>35^{\circ} \mathrm{C}$.
TR20, the number of tropical nights per year where $T_{\min }>20^{\circ} \mathrm{C}$.

Cool spell duration index (CSDI) or the total number of days being part of cool spells longer than 6 consecutive days in duration. A day is considered to belong to a cold spell if $T_{\min }$ is less than the calendar-day $T_{\min } 10$ th percentile centred on a 5-day window for the base period studied.

Warm spell duration index (WSDI) or heat wave index, or the total number of days being part of warm spells longer than six consecutive days in duration. A day is considered to belong to a warm spell if $T_{\max }$ is greater than the calendar-day $T_{\max }$ 90th percentile centred on a 5-day window for the base period studied.

$\mathrm{R} 10$, the number of days per year with heavy precipitation (daily precipitation $>10 \mathrm{~mm}$ ).

$\mathrm{R} 20$, the number of days per year with very heavy precipitation (daily precipitation $>20 \mathrm{~mm}$ ).

CWD, the maximum number of consecutive wet days per year where daily precipitation $>1 \mathrm{~mm}$

$\mathrm{CDD}$, the maximum number of consecutive dry days per year where precipitation $<1 \mathrm{~mm}$.

DTR, daily temperature range or annual mean difference between $T_{\max }$ and $T_{\min }$

Warm spells accounting for the total number of days per year with at least 3 and 6 continuous days with $T_{\max }$ greater than $35^{\circ} \mathrm{C}$ were also computed and associated with indices named WSDI-3d and WSDI-6d, respectively. Cold spells accounting for the total number of days per year with at least 3 and 6 continuous days with $T_{\min }$ less than $0^{\circ} \mathrm{C}$ were also computed and associated with the variables CSDI-3d and CSDI-6d. The climate extreme indices were also computed for each phenological stage (budburst, flowering and véraison) based on the previously mentioned conventional Julian calendar monthly configuration and the mixed Tinta Roriz-Touriga Franca local grapevine varietal phenological model. The climate extreme indices related to cold surface atmospheric conditions were computed for the dormancy period (November to March) and extended only to the budburst stage during the grapevine-growing season. Overall, 150 variables related to climate extreme indices were computed at the annual scale and specific phenological-stage timings for the grapevine. A list of pertinent abbreviations is given in Table $\mathbf{S} 2$.

\subsection{DDR yield and quality data}

The average yield ( $\mathrm{hl} / \mathrm{ha}$ ) of all types of wine produced in the DDR for the recent-past 1986-2005 period was considered. Data were available from Corte-Real (2014) consisting of a compilation of data from the Portuguese Office for 
National Statistics (INE), taking into account the increase in planted areas since 1982. Data on Port vintage ratings were selected from Corte-Real et al. (2016) and Corte-Real (2014), taking into account the scores of a set of eight renowned vintage charts and the IVDP regulating board ratings (Table S3) which classifies Port wines as Vintage Port wines only when very high standards of organoleptic quality are met. As Port wine makes up to $60.4 \%$ of the total production of wine in the DDR (IVDP, 2017b), it can be assumed that Port wine quality ratings are highly correlated with the overall vintage quality in the DDR. The original vintage scores for the recent-past period (1986-2005) can be found in Table S4 as compiled in Corte-Real et al. (2016).

\section{5 | WRF validation and statistics}

The April to October GST values and the estimated dates for véraison from the mixed Tinta Roriz-Touriga Franca local grapevine varietal phenological model for the selected cells were used to validate the WRF-ERA recent-past modelling simulations against GST estimates from the $0.25^{\circ}$ horizontal resolution E-OBS (Haylock et al., 2008) and data on grapevine phenology observations taken over 10 years in a vineyard within the DDR (Alves et al., 2013). As the maturity stage is highly dependent on the style of wine to be produced and cannot be defined with high precision, these records only report chronological duration up to the onset of the véraison phenological stage. Therefore, this phenological stage was chosen to evaluate the suitability of using the WRF-ERA recent-past simulations when the mixed Tinta Roriz-Touriga Franca local grapevine varietal phenological model is applied.

Once the WRF-ERA model outputs were validated, the data on standardized vintage yield and vintage rating scores, and the standardized climate parameters, bioclimatic and climate extreme indices estimated for the WRF-ERA 1986-2005 recent past were submitted to Spearman correlation tests to look for significant associations. For the case of the MB and IVDP vintage scoring systems, Mann-Whitney statistical tests were performed as they could be grouped into just two groups of vintages (IVDP 1 Vintage Port, IVDP 0 Non-Vintage Port, MB $\leq 3$ Good/Very Good vintage, MB $\geq 4$ Excellent/Award vintage). These tests were selected considering that many of the variable distributions analysed were non-normal as is often the case for climate extreme events (e.g., summer storms, warm or cold spells). Finally, based on the significant associations found for the WRFERA recent-past data set, some representative climate parameters and indices were estimated by using the WRFMPI simulations for the recent-past and future scenarios to assess their potential impact on wine production for the whole DDR and the grapevine-cultivated areas as derived from CORINE 2006 (Caetano et al., 2009).

\section{4 | RESULTS AND DISCUSSION}

Results will be discussed in the same order as the workflow diagram (Figure 2) used in Section 3. First, the quality of the WRF-ERA data set for the DDR is introduced. A presentation and discussion of significant relations found between climate parameters, grapevine bioclimatic indices and climate extremes and vintage yield and Port wine rating scores in the study area follows. Finally, an assessment regarding the possible impacts of climate change in the DDR is performed by using WRF-MPI data sets for the recent-past and future RCP8.5 GHG emission climate scenarios.

\section{1 | WRF-ERA data validation}

Owing to the lack of detailed temperature records in the region covering the whole DDR area, E-OBS is considered here as the reference for validation purposes. The simulations used in this study, performed with the WRF forced by ERA (and also by MPI), were generally validated (at $9 \mathrm{~km}$ horizontal resolution) by Marta-Almeida et al. (2016) for the reference climate (1986-2005) by comparison with gridded temperature data sets derived from meteorological station records for Spain and Portugal. Marta-Almeida et al. (2016) reported an acceptable comparison of both model configurations applied in this work (WRF-ERA and WRF-MPI) when daily climatologies of temperature and precipitation were compared with observational data sets across coarse climatological subregions. Pereira et al. (2017) used the same simulations outputs and validated temperature (at $9 \mathrm{~km}$ horizontal resolution) and its extremes and other temperature-derived measures with those obtained from E-OBS.

Figure 3 shows the spatial pattern of the grapevine April to October GST over the Douro Valley as modelled for the D3 $9 \times 9$-km WRF-ERA configuration.

The $9 \times 9-\mathrm{km}$ resolution WRF simulations forced by ERA-Interim reanalysis resulted in realistic patterns of surface atmospheric variables. Within the DDR, the GST values portray a west-east trend resulting from the orientation of the main valley itself and the increasing distance from the sea. Mean GST for the three DDR subregions are shown in Table 1 for WRF-ERA and E-OBS. Table 1 also portrays the resulting mean véraison dates along with the WRF-ERA April to October GST means obtained for each of the DDR subregions. The GST mean values are very close to those estimated based on the $0.25^{\circ}$ horizontal resolution E-OBS data set for the same years. Only the Douro Superior subregion presents an average véraison date within the 95\% confidence limits of the timings reported for the area by Alves 
F I G URE 3 Mean April to October growing-season average temperature (GST, ${ }^{\circ} \mathrm{C}$ ) as calculated from the $9 \times 9-\mathrm{km}$ 1986-2005 WRFERA simulations. The DDR limits are represented with its main subregions (Baixo Corgo, Cima Corgo and Douro superior), and grapevine-cultivated areas are derived from CORINE 2006

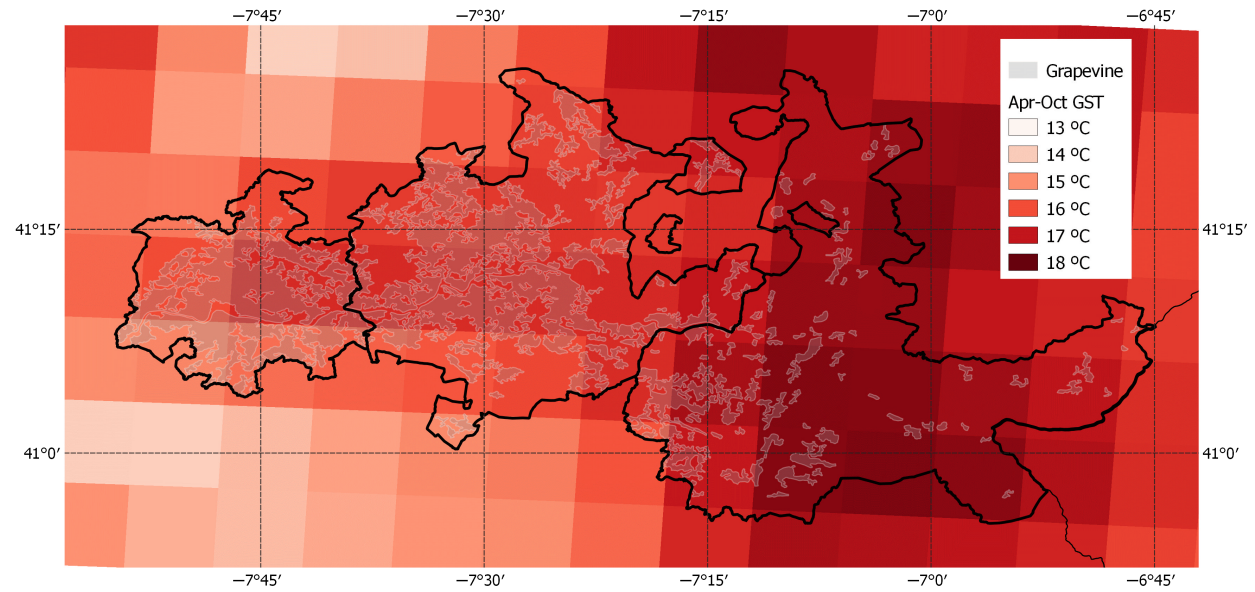

et al. (2013). These rather delayed phenological figures could be attributed to an important difference between the average height of the selected WRF-ERA cells $(536 \mathrm{~m}$ for the Baixo Corgo subregion, $526 \mathrm{~m}$ for the Cima Corgo subregion and $452 \mathrm{~m}$ for the Douro Superior subregion) and that of the field plot where the phenological dates were observed (Quinta da Cavadinha, $205 \mathrm{~m}$ ). Based on these results, only one WRF-ERA $9 \times 9-\mathrm{km}$ cell representative of the mean conditions of the Douro Superior subregion was used for the correlation analysis.

\section{2 | Vintage yield and quality in relation to climate}

All of the rating charts have strong $(>0.6)$ and significant Spearman's correlation coefficients with at least two other charts (Table 2). WA is the exception, not correlating significantly with any one of the others. As the number of Port vintages specifically evaluated was higher in IVDP (20), WE (19), MB (17) and DC (14) compared with the other charts, these were the final charts selected to analyse the relationship between Port wine vintage ratings and climate. It is worthwhile noticing that yield presented significant negative correlations with two of the rating charts (WS, VT).

T A B L E 1 GST and véraison statistics for the three DDR subregions

\begin{tabular}{lllll} 
1986-2005 recent-past period & & \\
\hline & \multicolumn{3}{c}{ GST means $\left({ }^{\circ} \mathbf{C}\right)$} & \multicolumn{2}{l}{$\begin{array}{l}\text { Véraison date } \\
\text { (Julian day) }\end{array}$} \\
\cline { 2 - 5 } DDR subregion & WRF-ERA & E-OBS & Model & Field \\
\hline Baixo Corgo & 16.0 & 16.1 & 241 & $175-229^{\mathrm{a}}$ \\
Cima Corgo & 16.4 & 16.8 & 237 & \\
\hline Douro Superior & 17.4 & 17.4 & 224 & \\
\hline
\end{tabular}

${ }^{a}$ The date range given represents the $95 \%$ confidence limits for the onset of véraison in a representative vineyard in the study area.
This suggests an inverse relationship between vintage yield and Port wine vintage ratings.

Table 3 shows the significant moderate $(>0.5)$ and strong $(>0.6)$ associations found between the climate parameters and indices, as computed from the daily temperature and precipitation records from the Douro Superior subregion WRF-ERA cell, and the corresponding vintage yield and Port wine vintage rating records for the recent-past 1986-2005 time period. It is worth noticing that, within a viticulture context, correlation values as low as 0.54 have been considered highly relevant in a study relating water deficit to vintage quality (van Leeuwen and Darriet, 2016). These correlations are also similar in range to those found in another study at a close latitude (Galicia, north-west Spain) relating wine production to climate parameters (Lorenzo et al., 2012). Several correlations were found by using Mann-Whitney tests too. Some associations (e.g., $T_{\max -\mathrm{b}}$, $T_{\text {max-v }}$, SU25-v, SU35-f, CDD-f) were identified using the phenological modelling configuration, showing the benefit of using thermal timings based on accumulated heat rather than using only the conventional monthly schemes based on Julian calendar dates.

Elevated growing-season April to September average temperatures ( $T_{\text {ave }}$ Apr-Sep) and heat sums (GDD-AprSep, $\mathrm{HI}$ ), lower rates of precipitation from May (P-May) accompanied by not too dry conditions during the flowering stage (CDD-f), and high daily maximum temperatures $\left(T_{\max -\mathrm{v}}\right)$ associated with a high frequency of summer days (SU25-v) from véraison to maturity time are related to high grapevine yields. These results are consistent with other studies performed in the area, such as those of Corte-Real (2014), Fraga and Santos (2017) and Santos et al. (2011; 2013).

Wine quality ratings relate differently to meteorological conditions than yield. Port wine vintage ratings appear to be positively associated with sufficient cold requirements during dormancy (FD0-JanMar, CSDI-3d-JanMar), elevated daily maximum temperatures during budburst followed by a high incidence of May summer days (SU25-May) and very 
T A B L E 2 Correlation coefficients among the different vintage rating charts

\begin{tabular}{|c|c|c|c|c|c|c|c|c|c|}
\hline & Yield & BBR & DC & IVDP & MB & SWE & VT & WE & WS \\
\hline BBR & -0.075 & & & & & & & & \\
\hline DC & -0.083 & $0.939 * *$ & & & & & & & \\
\hline MB & -0.227 & 0.626 & $0.821 * *$ & 0.447 & & & & & \\
\hline SWE & 0.001 & 0.583 & 0.466 & $0.749 * *$ & 0.550 & & & & \\
\hline WE & -0.191 & 0.467 & 0.489 & $0.607^{* *}$ & $0.751 * *$ & $0.632 * *$ & $0.673^{* *}$ & & \\
\hline WS & $-0.548 *$ & 0.772 & 0.830 & 0.412 & $0.772 *$ & 0.482 & $0.913^{* *}$ & $0.747 * *$ & \\
\hline WA & -0.118 & 0.445 & 0.426 & NaNNA & 0.000 & -0.031 & -0.320 & -0.061 & 0.088 \\
\hline
\end{tabular}

Note: Vintage rating charts acronyms: BBR, Berry Bros \& Rudd; DC, decanter; IVDP, Instituto dos Vinhos do Douro e do Porto; MB, Michael Broadbent; SWE, Sotheby's Wine Encyclopaedia; VT, vintages; WA, wine advocate; WE, wine enthusiast; WS, wine spectator. As it can be observed in Table S4, there are only six WA-rated vintages which were all qualified as top-vintage years with a value of 1 according to the IVDP vintage rating chart. Therefore, it is not possible to compute a Spearman's correlation coefficient for this case.

Abbreviation: NaNNA, not a number, not available.

*95\% significance level; **99\% significance level.

hot days $\left(T_{\max }>35^{\circ} \mathrm{C}\right)$ from flowering to véraison (SU35-f) associated with prolonged periods without rain (CDD-f, CDD-JunJul). Finally, moderate amounts of rain commonly associated with isolated summer storms (P-Aug, R10-Aug) help to relieve severe water stress and appear to be associated with good Port vintages too. According to van Leeuwen and Darriet (2016), these conditions are favourable to a decrease in bud fertility and the development of a smaller berry size, which result in a smaller number of grapes developed per vine with a greater chance of a balanced supply of photoassimilates to them.

\section{3 | Climate change analysis: Reference and future scenarios}

\subsection{1 | Climate parameters and indices}

GST, véraison onset and SU25, SU35 and FD0 climate extreme indices were selected as representative due to their simple definition and significant association with vintage yield and Port wine vintage ratings as found in the previous section. Table 4 shows the estimated climate-related and indices based on the WRF-ERA and WRF-MPI simulations. The WRF-MPI 1986-2005 data set manifests a cooler bias for GST $\left(-1.1^{\circ} \mathrm{C}\right)$, véraison (14-day delay), SU25 ( -14 days) and SU35 ( -3 days) but not for FD0 where the figures are greater in WRF-ERA (+11 days). With respect to the bioclimatic indices, there is only agreement in the mean general Winkler class for the whole DDR (Ib) and CI $(\mathrm{CI}+2)$, with HI and DI having mean warmer and drier conditions, respectively, in WRF-ERA. Despite the differences found in means and bioclimatic class labels, the standard deviations are very close in most cases.
Performing a specific fit of the WRF-MPI data set for the DDR is beyond the scope of this work. Instead, warm years offsetting the cooler bias during the April to October grapevine-growing season of $-1.1^{\circ} \mathrm{C}$ detected in the $9 \times 9$-km MPI data set in the DDR area when compared with the WRF-ERA data set were selected to perform $1 \times 1-\mathrm{km}$ WRF-MPI D4 simulations that could be representative of extreme hot seasons for the recent-past and future climate conditions in the study area: namely, the years 2000 , 2049 and 2097 were selected this way (highlighted in bold in Table S5). Also, the maximum average temperature of the peak summer months (i.e., July to September) was considered to select 2097 instead of 2098 for the long-term future.

\subsection{2 | From reference to future climate scenarios}

Results concerning FD0, SU25 and SU35 for the WRF-MPI 2000, 2049 and 2097 simulations are shown in Figure 4. FD0 values are lower in the western subregion and could reach higher values close to 10-20 days per year at the highest elevations in the central and eastern subregions. The differences between the results obtained for 2049 and 2097 indicate rates of change between 0 and 10 fewer frost days per year for most of the DDR, with the greatest decrease in rates present at the highest elevations of the central and eastern subregions. The highest incidences for SU25 with values greater than 100 days per year are found at the lowest elevations across the DDR, with greater extension in the eastern subregion. Rates of change range mostly between 10 and 20 SU25 days more per year for 2049, and 30 and 40 more SU25 days per year by 2097, with higher increases at higher elevations. With respect to SU35, higher values 
T A B L E 3 Significant moderate $(>0.5)$ to strong $(>0.6)$ correlations between vintage yield and quality rating charts and climate parameters and indices for the 1986-2005 recent-past period

\begin{tabular}{|c|c|c|c|c|c|}
\hline \multicolumn{6}{|c|}{ 1986-2005 recent-past period } \\
\hline \multirow[b]{2}{*}{ Statistical test } & Yield & WE & DC & MB & IVDP \\
\hline & \multicolumn{3}{|c|}{ Spearman's correlation $\rho$} & \multicolumn{2}{|c|}{ Mann-Whitney $U$} \\
\hline \multicolumn{6}{|l|}{ Growing season } \\
\hline$T_{\text {ave }}-\operatorname{AprSep}\left({ }^{\circ} \mathrm{C}\right)$ & $0.519 *$ & & & & \\
\hline GDD-AprSep & $0.575^{* *}$ & & & & \\
\hline HI (unitless) & $0.581^{*}$ & & & & \\
\hline SU25 (days) & $0.555^{*}$ & & & & \\
\hline \multicolumn{6}{|l|}{ Dormancy } \\
\hline FD0-JanMar (days) & & & $0.580^{*}$ & 0.038 & 0.025 \\
\hline CSDI-3d-JanMar (days) & & & & 0.048 & 0.037 \\
\hline \multicolumn{6}{|l|}{ Budburst } \\
\hline$T_{\max -\mathrm{b}}\left({ }^{\circ} \mathrm{C}\right)$ & & & & 0.015 & \\
\hline SU25-May (days) & & $0.645^{* *}$ & & & 0.044 \\
\hline P-May (mm) & $-0.538^{*}$ & & & & \\
\hline \multicolumn{6}{|l|}{ Flowering } \\
\hline SU35-f (days) & & $0.723 * *$ & & & \\
\hline CDD-f (days) & $-0.612 * *$ & $0.475^{* *}$ & & & \\
\hline CDD-JunJul (days) & & $0.592 * *$ & $0.678^{*}$ & & 0.069 \\
\hline \multicolumn{6}{|l|}{ Véraison } \\
\hline$T_{\max -\mathrm{v}}\left({ }^{\circ} \mathrm{C}\right)$ & $0.533 *$ & & & & \\
\hline SU25-v (days) & $0.524 *$ & & & & \\
\hline P-Aug (mm) & & $0.423 * *$ & & & \\
\hline R10-Aug (days) & & $0.559 * *$ & & 0.023 & 0.037 \\
\hline
\end{tabular}

Note: CSDI-3d-JanMar (days), cold spell index accounting for the total number of days from January to March with at least three continuous days with $T_{\min }<0^{\circ} \mathrm{C}$; CCD-JunJul (days), maximum number of continuous dry days $(p<1 \mathrm{~mm}$ ) from June to July; CDD-f (days), maximum number of continuous dry days $(p<1 \mathrm{~mm}$ ) from the flowering to the véraison stage; FD0-JanMar (days), number of frost days from January to March; GDD-AprSep, April to September growing-degree days; HI (unitless), Huglin index; P-Aug (mm), August total precipitation; P-May (mm), May total precipitation; R10-Aug (days), number of days with heavy precipitation during August $(p>10 \mathrm{~mm}$ ); SU25 (days), number of summer days per year; SU25-May (days), May summer days; SU25-v (days), number of summer days from the véraison stage to the end of September; SU35-f (days), number of very hot days from the flowering to the véraison stage; $T_{\text {ave }}$-AprSep $\left({ }^{\circ} \mathrm{C}\right)$, growing-season April to September average temperature; $T_{\text {max-b }}\left({ }^{\circ} \mathrm{C}\right)$, mean of daily maximum temperatures from the budburst to the flowering stage; $T_{\max -\mathrm{v}}$ $\left({ }^{\circ} \mathrm{C}\right)$, mean of daily maximum temperatures from the véraison stage to the end of September.

*95\% significance level; **99\% significance level. ranging between 20 and 40 SU35 days per year are found across the valleys with the highest values found in the eastern subregion. There is no increasing tendency for the 2049 simulation but SU35 numbers increase by 30 or even 50 days per year in the 2097 simulation.

Figure 5 shows the results after applying the local grapevine varietal phenological model to the WRF-MPI simulations. It can be observed that the earliest budburst dates, with values as low as 61 (March 1st) for the eastern subregion or 66 (March 6th) for the central and western regions, are associated with lower elevations with greater areal extension in the eastern subregion. The 2049 simulation shows a delay of the budburst reflecting less favourable conditions for this phenological stage than those present in the 2000 simulation. However, the 2097 simulation indicates advancements in the order of 10 or 20 days associated mostly with the higher elevations. Véraison has mean values of 206 (July 24) for the western and eastern subregions and 210 (July 28) for the central one. The 2049 simulation is associated with no or little advancement (up to 10 days) for this phenological stage. However, a clear advancement of between 10 and 30 days for véraison is observed in the 2097 simulation, with the highest advancement rates associated with the highest elevations. Finally, both the 2049 and the 
T A B L E 4 Differences of means and standard deviations between WRF-ERA and WRF-MPI for some representative climate-related parameters and indices in the DDR

\begin{tabular}{|c|c|c|c|c|}
\hline \multicolumn{5}{|c|}{ 1986-2005 recent-past climate scenario } \\
\hline & \multicolumn{2}{|c|}{ WRF-ERA } & \multicolumn{2}{|c|}{ WRF-MPI } \\
\hline & $\bar{x}$ & $\sigma$ & $\bar{x}$ & $\sigma$ \\
\hline $\begin{array}{l}\text { April to October growing-season } \\
\text { average temperature GST }\left({ }^{\circ} \mathrm{C}\right)\end{array}$ & 16.7 & 0.38 & 15.6 & 0.37 \\
\hline Véraison onset (Julian day) & 234 & 4 & 248 & 3 \\
\hline $\begin{array}{l}\text { Number of summer days } \\
\text { per year SU25 (days) }\end{array}$ & 77 & 6 & 63 & 6 \\
\hline $\begin{array}{l}\text { Number of very hot days } \\
\text { per year SU35 (days) }\end{array}$ & 4 & 1 & 1 & 0.3 \\
\hline $\begin{array}{l}\text { Number of frost days } \\
\text { per year FD0 (days) }\end{array}$ & 36 & 4 & 25 & 3 \\
\hline WI (GDD) & $\mathrm{Ib}$ & 75 & $\mathrm{Ib}$ & 70 \\
\hline HI (unitless) & $\mathrm{HI}-1$ & 85 & $\mathrm{HI}-2$ & 79 \\
\hline $\mathrm{DI}(\mathrm{mm})$ & $\mathrm{DI}+1$ & 14 & DI -1 & 10 \\
\hline $\mathrm{CI}\left({ }^{\circ} \mathrm{C}\right)$ & $\mathrm{CI}+2$ & 0.2 & $\mathrm{CI}+2$ & 0.2 \\
\hline
\end{tabular}

2097 simulations indicate a shortening of the duration of the budburst to véraison growing cycle ranging between 5 and 25 fewer days across the DDR. The specific rates of change between the 2000 recent-past simulation and the 2049 and the 2097 future ones for the grapevine areas present in the DDR as derived from the CORINE 2006 data set for FD0, SU25, SU35, budburst, veraison and the length of the grapevine growing cycle between budburst and véraison can be found in Figure 6.

Figure 7 illustrates mean April to October GST, April to October GSP and WI thematic layers derived from the selected representative WRF-MPI recent-past (2000), midterm future (2049) and long-term future (2097) simulations. For the year 2000 recent-past simulation, most cell values within the DDR are associated with the temperate and warm class, with some occurrence of the intermediate class for GST, rainfall values between 200 and $400 \mathrm{~mm}$ for GSP, and a diverse set of WI regions present ranging from $\mathrm{Ib}$ to V. The higher GST values and WI regions are associated with the lower elevations across the Douro River valley and its tributaries also increasing their presence as they are more distant from the Atlantic influence towards the east. The GSP spatial pattern results both from the yearly storm distribution and the variable topographical characteristics present in the area.

For the year 2049 mid-term simulation, GST intermediate conditions decrease their presence, whereas warm conditions become more frequent; there is an increase of cells with only 100-200 mm of GSP, and WI regions Ib and II reduce their area at the same time as IV and V increase their coverage.
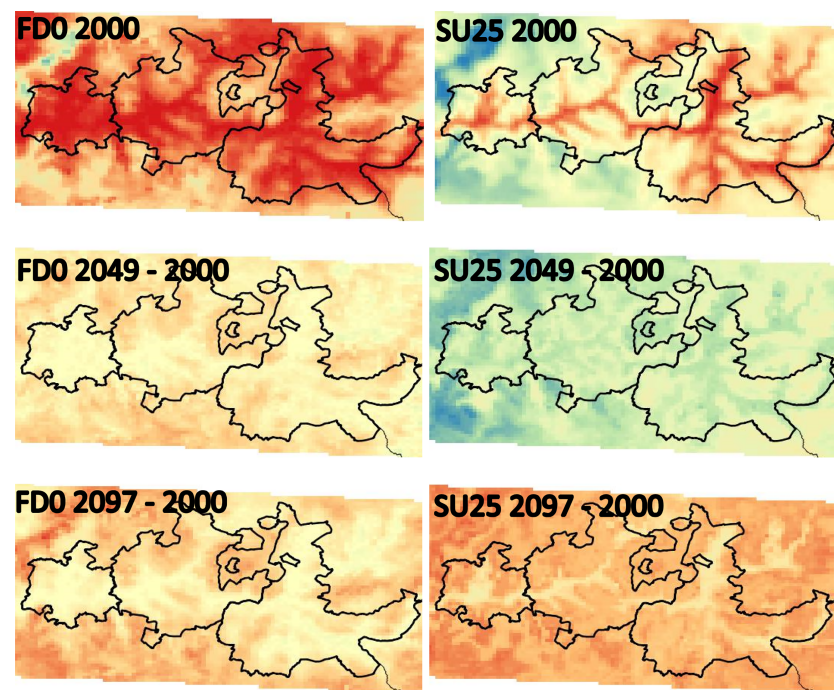

FDO

\begin{tabular}{|c|}
\hline Differences \\
-30 days \\
-20 days \\
-10 days \\
0 days \\
10 days \\
20 days \\
30 days
\end{tabular}
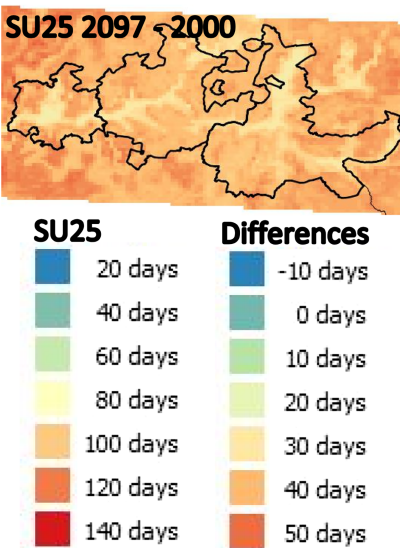
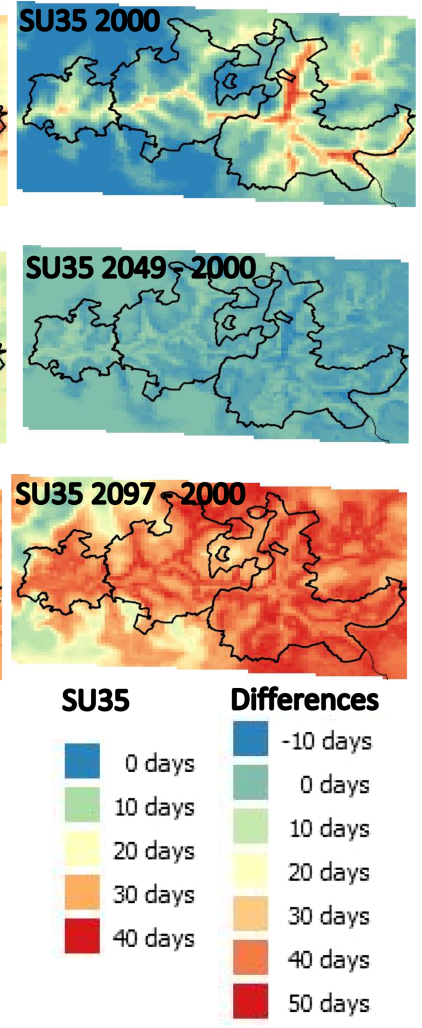

FIGURE 4 FD0, SU25 and SU35 and associated rates of change thematic layers as derived from the very high-resolution $1 \times 1$-km WRFMPI RCP8.5 hourly simulations for selected representative recent-past (2000), mid-term future (2049) and long-term future (2097) years in the DDR 
F I G URE 5 Budburst, véraison and budburst to véraison grapevine growing-season length and associated rates of change thematic layers as derived from the very high-resolution $1 \times 1-\mathrm{km}$ WRF-MPI RCP8.5 hourly simulations for selected representative recent-past (2000), mid-term future (2049) and long-term future (2097) years in the DDR
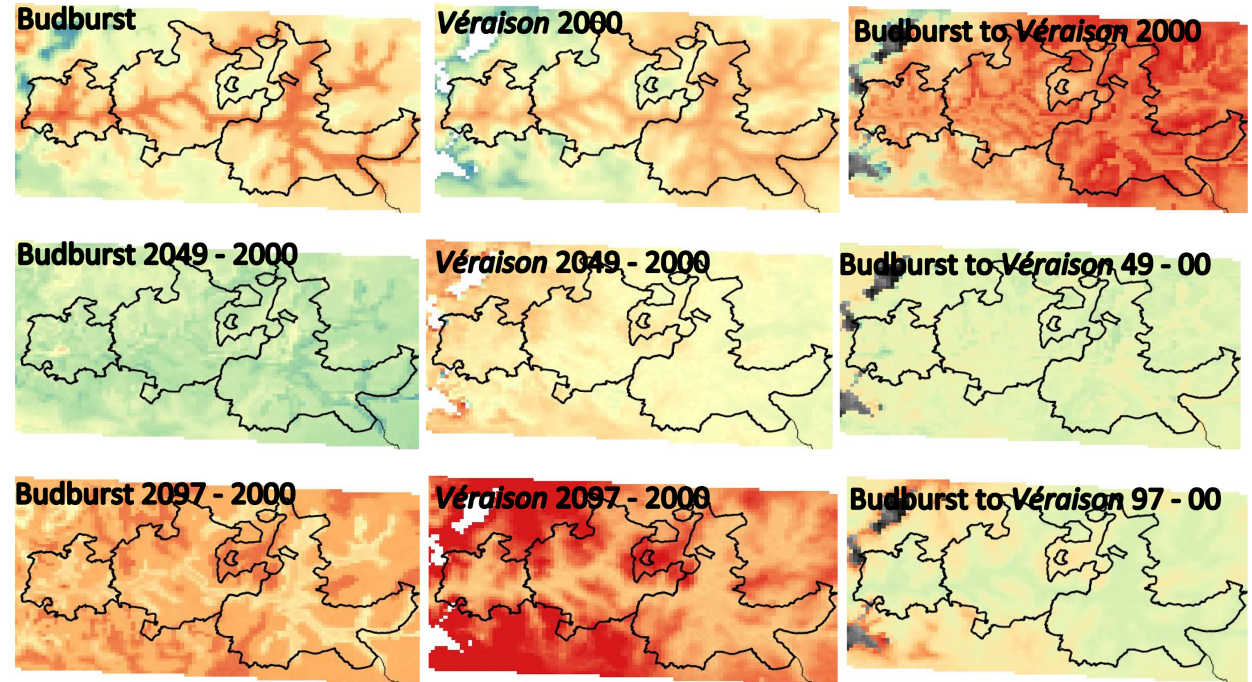

\begin{tabular}{|c|c|c|c|c|c|}
\hline Budbreak & Differences & Véraison & Differences & Budburst to & Differences \\
\hline \multirow{2}{*}{ Julian calendar day } & -40 days & Julian calendar day & -30 days & Véraison & -75 days \\
\hline & -30 days & 150 & -20 days & 110 days & -60 days \\
\hline 50 & -20 days & 175 & -10 days & 125 days & -45 days \\
\hline 75 & -10 days & 200 & 0 days & 140 days & -30 days \\
\hline 100 & 0 days & 225 & 10 days & 155 days & -15 days \\
\hline 125 & 10 days & 250 & 20 days & 170 days & 0 days \\
\hline \multirow[t]{3}{*}{150} & 20 days & 275 & 30 days & 185 days & 15 days \\
\hline & 30 days & 300 & & & 30 days \\
\hline & 40 days & & & & \\
\hline
\end{tabular}

Finally, the year 2097 long-term MPI-WRF future simulation indicates the disappearance of temperate conditions which are substituted either by warm or very warm areas; GSP values fall below $300 \mathrm{~mm}$ with about half of the cells having only $200 \mathrm{~mm}$ or less, and there is a continuation of WI diversity loss towards the warmer end, with only regions $\mathrm{IV}$ and $\mathrm{V}$ being present and extensive areas considered as too warm for wine production.

Figure 8 illustrates the HI, DI and CI thematic layers derived from WRF-MPI simulations for recent-past (2000), mid-term future (2049) and long-term future (2097) years in the DDR. For the year 2000 recent-past simulation, most cell values within the DDR are associated with the temperate, temperate-warm and warm classes, with the presence of the cooler classes at higher elevations. DI ranges between the moderately dry and the sub-humid classes, with the drier areas associated with topographical valley lows and the absence of storms. CI is also represented almost exclusively by the very cool and cool night classes, with higher values associated with lower elevations especially in the Douro Superior subregion. For the year 2049 mid-term future simulation, HI temperate conditions are reduced in area whereas the temperate-warm and warm classes become more frequent; DI continues to range between moderately dry and sub-humid classes depending on topography and annual storm coverage, and there is a marked shift in CI from very cool or cool night conditions to temperate or warm night conditions.

Finally, the year 2097 long-term MPI-WRF future simulation indicates the disappearance of the temperate and temperate-warm conditions which are substituted by either warm or very warm areas; DI undergoes a marked shift to very dry conditions at the lower elevations in the central and eastern subregions, and there is an increase of CI warm night areas mainly associated with topographical lows.

In Figure 9, sets of probability density function graphs for the grapevine mean GST, GSP, WI, HI, DI and CI are shown as derived for the mapped vineyard areas present in the DDR, which were identified by overlaying the Portuguese CORINE 2006 land-use map over the very highresolution $1 \times 1-\mathrm{km}$ WRF-MPI-based thematic layers. Clear shifts towards warmer and drier conditions are observed, as previously commented on for all the land included within the DDR limits. These shifts become more pronounced from the mid-term 2049 simulation to the long-term future 2097, except for CI which changes abruptly in the midterm future.

\section{5 | CONCLUSIONS}

The WRF-ERA 1986-2005 simulations for the DDR satisfactorily compare with April to October GST estimates based 
Decrease in number of days with $\operatorname{Tmin}<0^{\circ} \mathrm{C}$

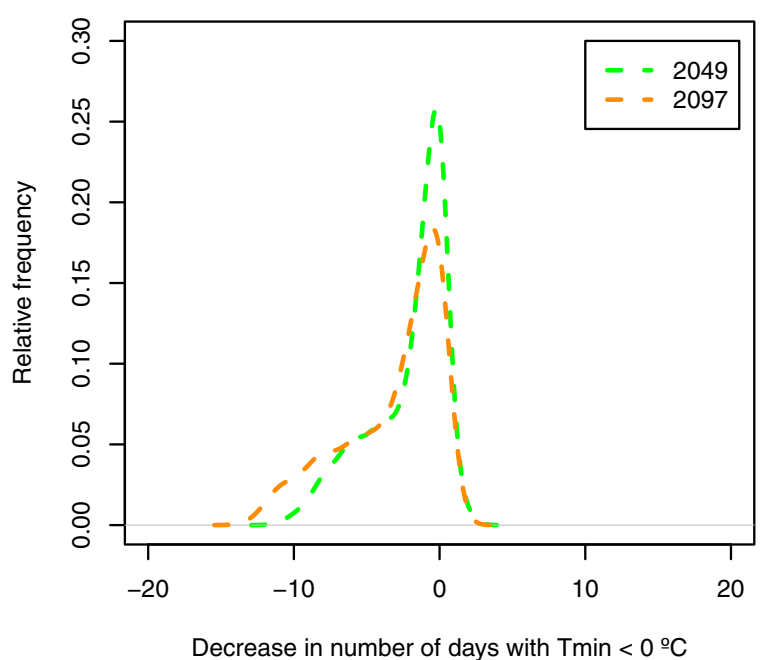

Increase in number of days with $\operatorname{Tmax}>35^{\circ} \mathrm{C}$

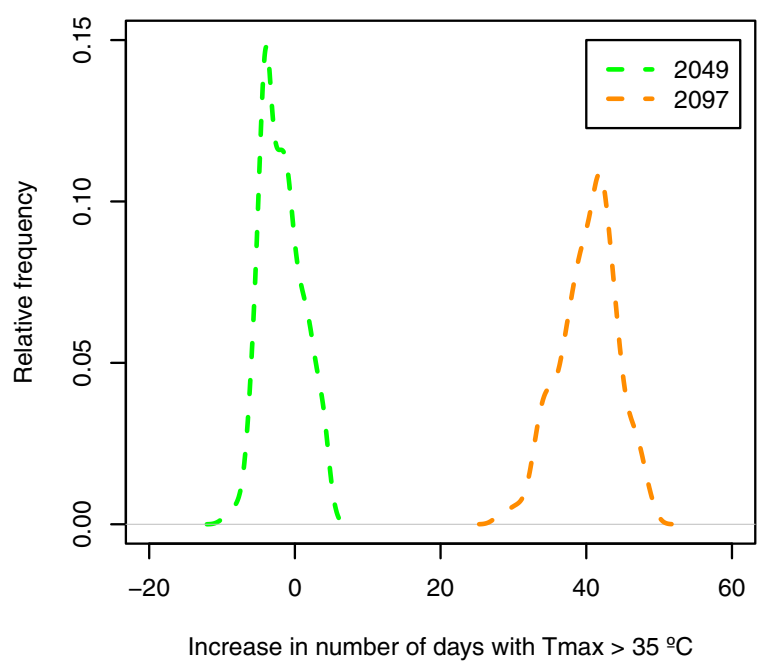

Véraison advancement

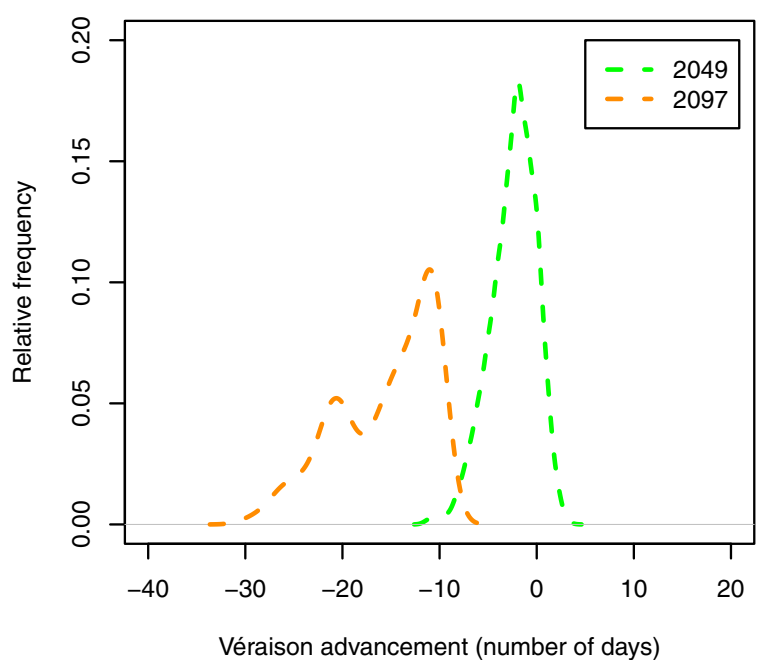

Increase in number of days with $\operatorname{Tmax}>25^{\circ} \mathrm{C}$

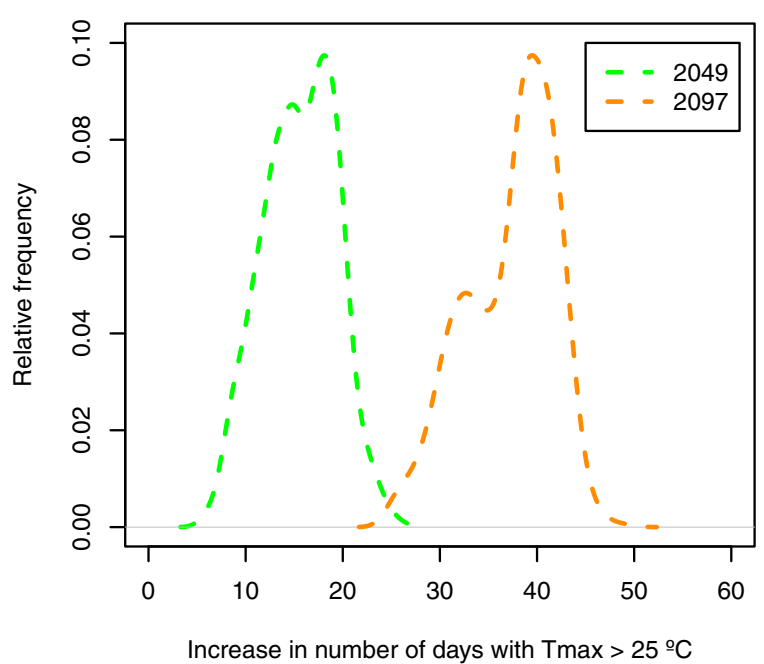

Budbreak advancement

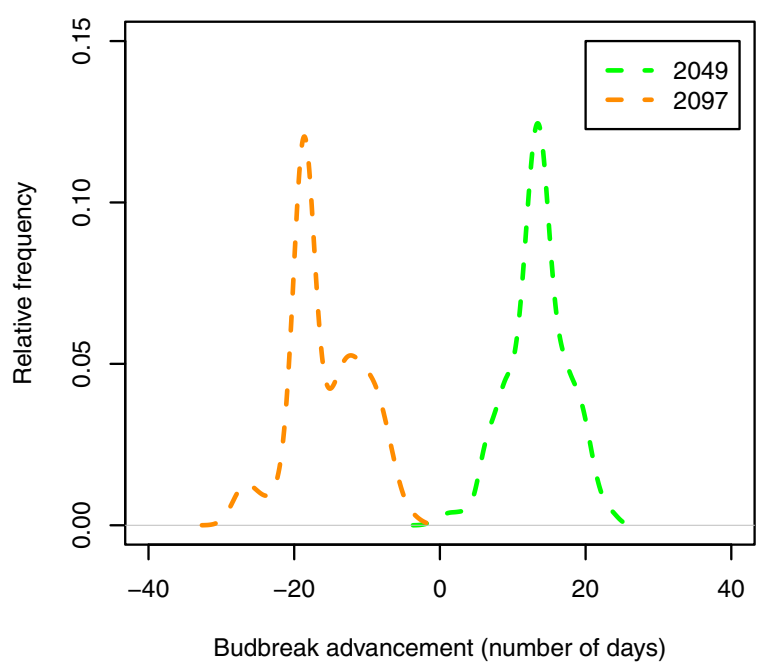

Budbreak to Véraison shortening

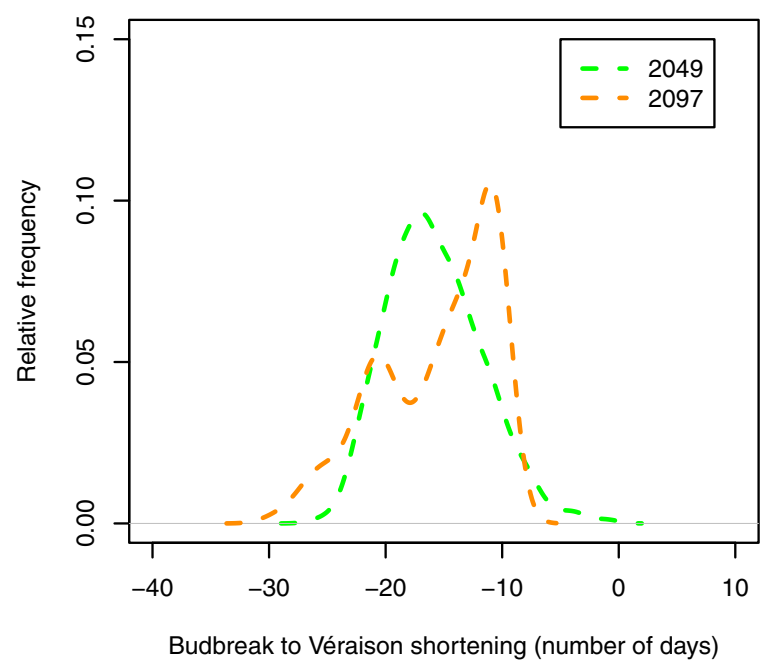

F I G U RE 6 Probability distributions of changes in FD0, SU25, SU35, budburst, véraison and budburst to véraison period as derived for mapped CORINE 2006 vineyard areas in the DDR 
F IGURE 7 Grapevine mean GST, GSP and WI thematic layers derived from very high-resolution $1 \times 1-\mathrm{km}$ WRF-MPI RCP8.5 hourly simulations for selected representative recent-past (2000), mid-term future (2049) and long-term future (2097) years in the DDR
F I G U R E 8 HI, CI and DI thematic layers derived from very high-resolution $1 \times 1$-km WRF-MPI RCP8.5 hourly simulations for selected representative recent-past (2000), mid-term future (2049) and long-term future (2097) years in the DDR
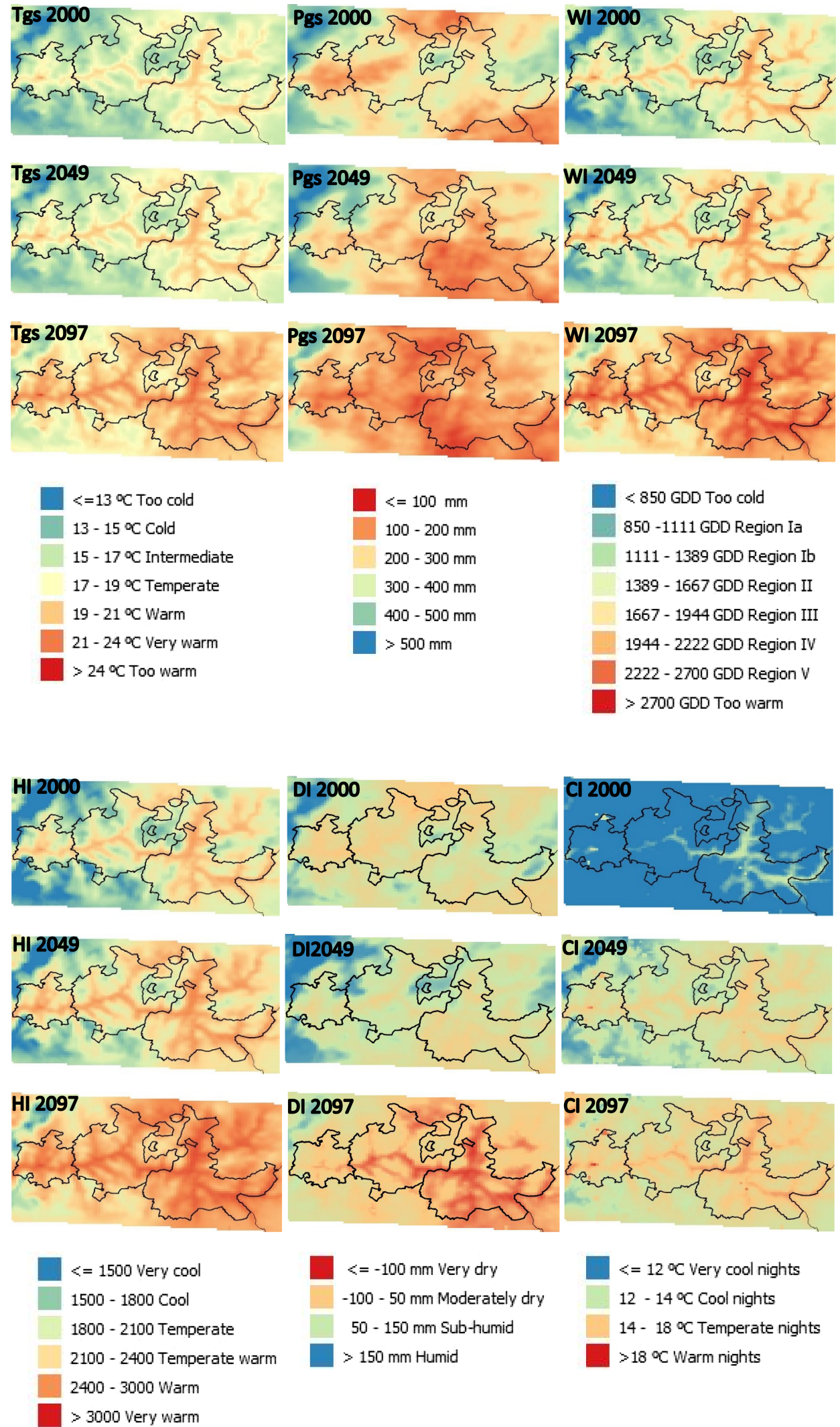

$<=-100 \mathrm{~mm}$ Very dry $-100-50 \mathrm{~mm}$ Moderately dry 50 - $150 \mathrm{~mm}$ Sub-humid $>150 \mathrm{~mm}$ Humid
$<=12 \circ$ C Very cool nights $12-14 \propto \mathrm{C}$ Cool nights $14-18{ }^{\circ} \mathrm{C}$ Temperate nights $>18 \propto \mathrm{C}$ Warm nights on the daily E-OBS data set. The application of a specific local grapevine varietal phenological model to derive phenological stages from the WRF-ERA daily simulations also gives satisfactory results when the elevational differences between the WRF cells and the phenological observational site are also considered. When a 4D $1 \times 1-\mathrm{km}$ configuration is used for selected warm GST years, the simulated phenological dates closely resemble those reported in the DDR: a 
Growing season mean temperature (GST)

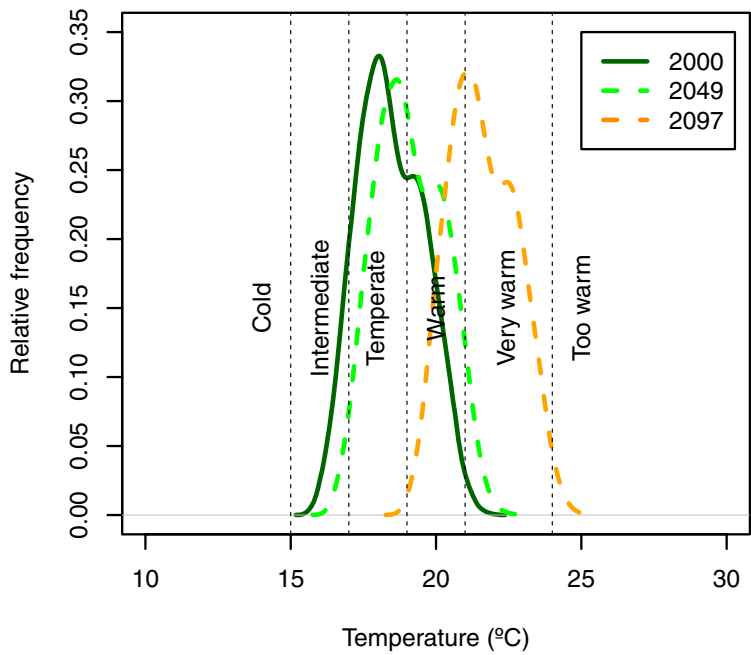

Growing season precipitation (GSP)

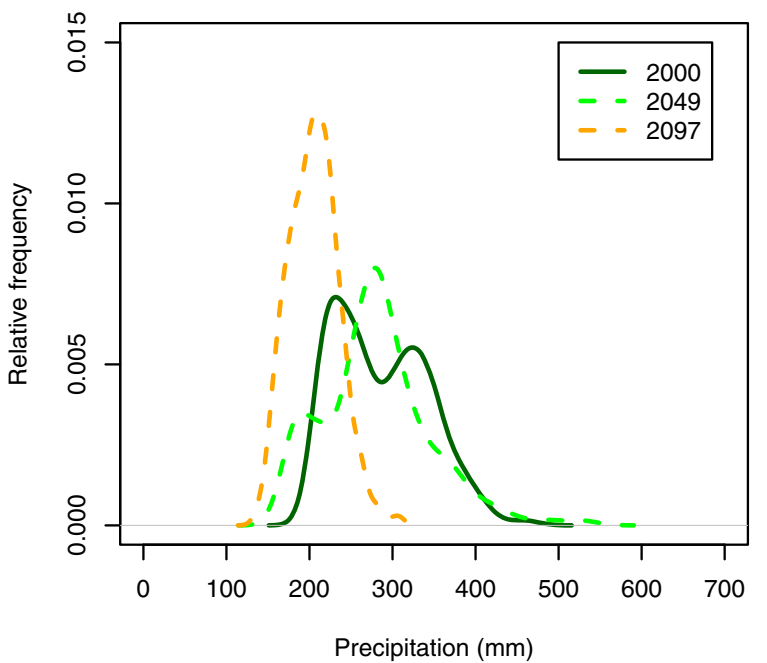

Winkler index (WI)

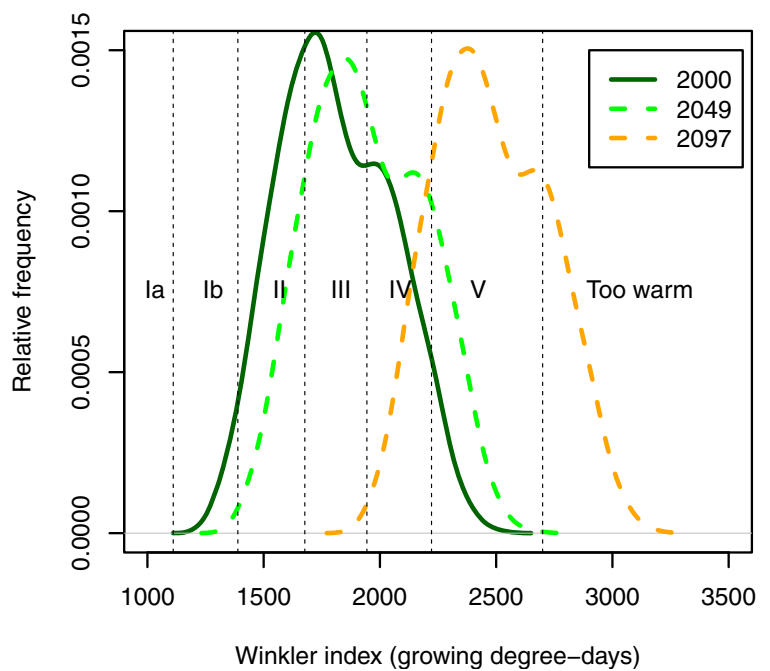

Heliothermal index (HI)

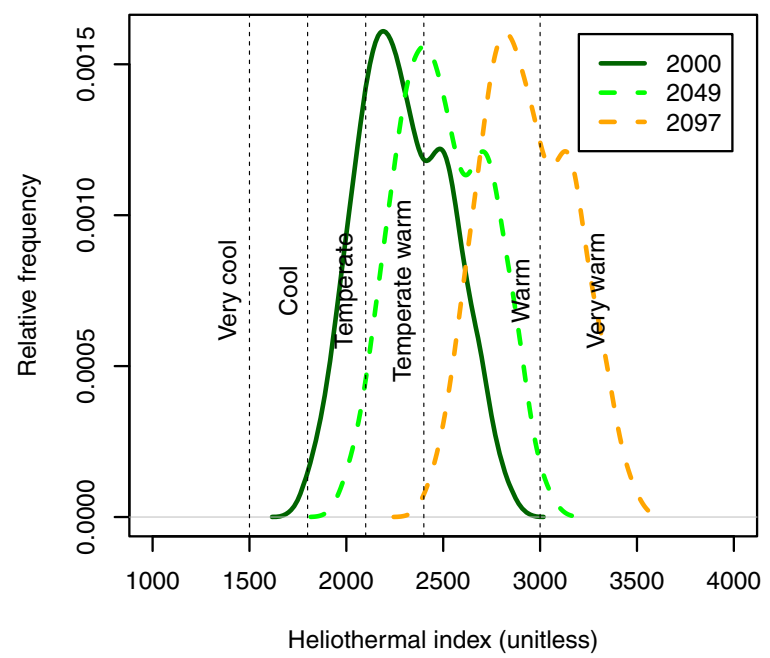

Dryness index (DI)

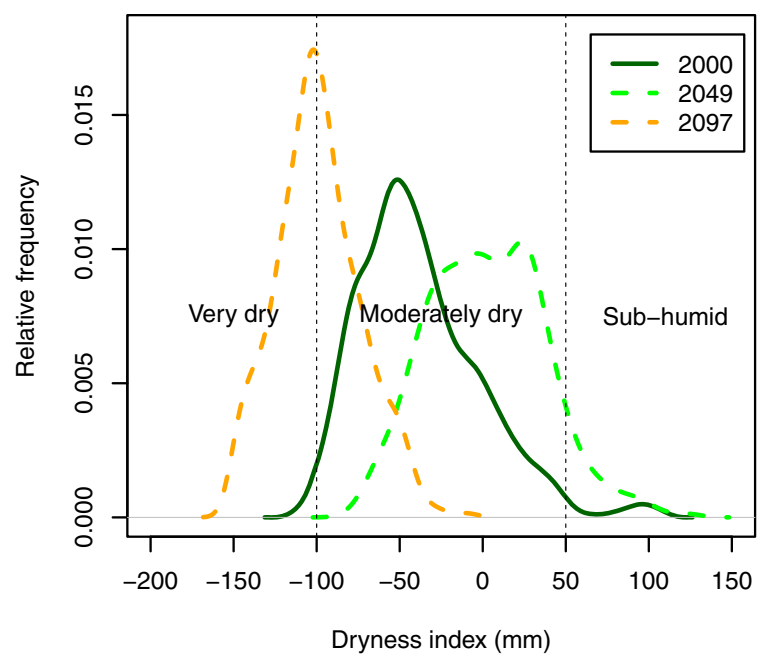

Night cold index $(\mathrm{Cl})$

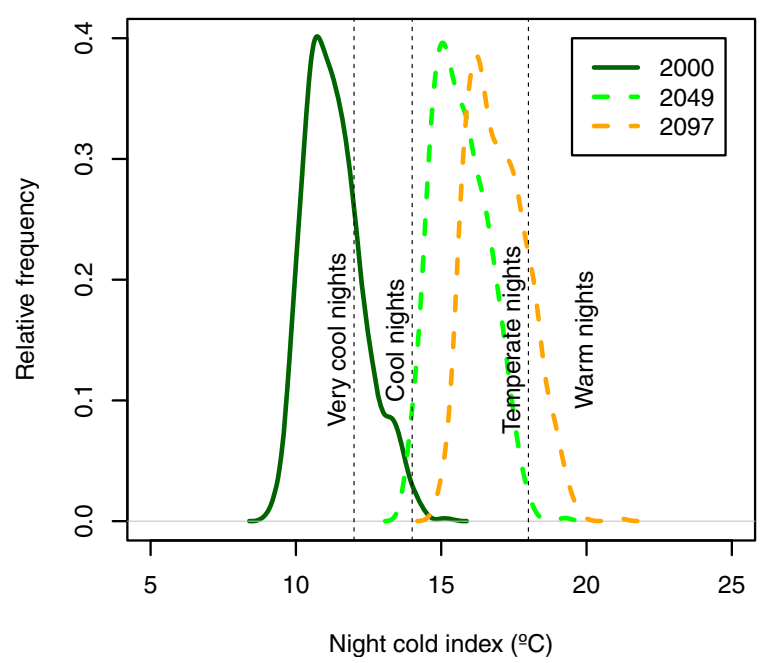

F IG U RE 9 GST, GSP, WI, HI, DI and CI probability distributions as derived for mapped CORINE 2006 vineyard areas in the DDR 
simulated mean value of the 83rd Julian calendar day for budburst, and the 207th Julian calendar day for véraison against observed values of 84th and 201st for budburst and véraison, respectively, for the specific Tinta Roriz-Touriga Franca thermal requirements adopted in this work. The year$20001 \times 1-\mathrm{km}$ dynamically downscaled WRF-MPI simulations also resulted in a closer agreement with the values of the viticultural bioclimatic indices and climate parameters estimated for the area by other studies such as those of Climaco et al. (2012) or Jones and Alves (2012).

Despite the limitations of the $9 \times 9-\mathrm{km}$ WRF-ERA simulations to reproduce the viticultural climate of an area of complex topography such as the DDR, it is still possible to select a representative cell or group of cells (e.g., the eastern subregion) to relate the 1986-2005 recent-past climate to vintage yield and Port wine vintage rating records in the area. Results confirm previous studies on the positive correlation between higher growing-season heat accumulation and greater vintage yields. Correlations found by using a thermal phenological model are often higher than those using conventional calendar-based monthly phenological divisions. Therefore, the phenological modelling also provided insight to understand the interactions between surface atmospheric conditions and vintage yield and quality in the DDR.

In general, the WRF-MPI very-high $1 \times 1-\mathrm{km}$ resolution simulations show an important increase in summer days (SU25) and very hot days (SU35) and an important reduction in frost days (FD0). These variations in climate extreme indices could relate to a higher incidence of heatwaves and fewer chilling units during dormancy and could pose a threat to maintenance of vintage quality. The simulations also illustrate an important advancement in phenology and shortening of the budburst to véraison period which could also expose the berries to warmer atmospheric conditions. Concerning bioclimatic parameters and indices, there is an increase in the average temperature during the vegetative period of the grapevine, and a concurrent decrease in GSP, with the greatest changes taking place in the second half of the $21 \mathrm{st}$ century. WI is typical of values associated with the production of high-quality wines in the recent past. However, the future WRF-MPI climate scenarios show a decrease in the diversity of WI regions towards warm or very warm areas associated with the intensive production of wines of intermediate quality, especially by the end of the century. HI also exhibits a potential change from temperate or temperatewarm conditions to warm or very warm conditions although this transition is more gradual than in the WI case. In the recent past, CI was associated mainly with very cool night conditions which are commonly related to the production of quality wines, but from the mid-term future scenario there is also a marked shift to temperate night conditions, reaching even warm night conditions for several areas at the end of the century. Finally, DI associates with a similar range of values between the moderately dry and the sub-humid class during the recent-past and mid-term future simulations, with results apparently associated mainly with the varied topography of the DDR and storm coverage. However, there is a considerable increase in water stress, which is already considered high under the present climate, at the end of the century.

The used methodology provides evidence for future strategies aimed to preserve the high-quality wines in the region and their typicality as it presents the current and future broad picture for the selected climate parameters, bioclimatic and extreme indices in the DDR using conventional standards accepted worldwide. Coupling of climate simulations with dynamic crop models capable to simulate grapevine growth while integrating plant phenotype, soil profiles, weather data, $\mathrm{CO}_{2}$ effects, and management options, has been applied at the European scale (Fraga et al., 2016). Other studies such as those of Santos et al. (2018) and Fraga et al. (2019) consider bioclimatic indices that incorporate nonlinear plant-temperature relationships (e.g., chilling portions or growing degree hours). Whereas these methods have great potential to provide more physiologically consistent results, their application in viticulture is still relatively scarce, and there is still a considerable need to validate calibration data, assumptions and results concerning Portuguese grapevine varieties and their growing conditions.

These results do not necessarily imply a dramatic decrease of viticultural suitability in the DDR in the midterm and long-term future scenarios, as adaptive measures can be taken and are already being taken by the grapevine growers in the area, and there is also a constant evolution of wine consumer preferences (van Leeuwen et al., 2013). In this sense, several actions can be proposed to preserve as much as possible the DDR wine typicity, taking current state-of-the-art knowledge (Hannah et al., 2013; Van Leeuwen and Darriet, 2016; Fraga et al., 2017) and previous works done in the study area (e.g., Jones and Alves, 2012) in a compromise to balance as much as possible economic, environmental and social costs. Short-term adaptations to increased temperatures and water deficits include the selection of suitable rootstocks, and late-ripening clones or varieties. Adapted training systems (e.g., gobelet), and canopy management (e.g., late pruning, reduced hedging and leaf pulling) can be applied to reduce water consumption, delay phenology or limit solar exposure too. Soil management can also be considered to increase the soil water holding capacity (SWHC) to promote a higher replenishment of the soil water storage by winter rains and growing-season storms. When there is need of irrigation, precise strategies such as deficit irrigation should be considered. It is also possible to relocate 
the vineyards in the long term to cooler sites such as higher elevations or areas with lower solar exposures or closer to the sea. These relocations should also be carefully planned in order to maintain as much as possible freshwater resources and natural habitats.

\section{ACKNOWLEDGEMENTS}

The authors wish to thank the DOUROZONE project (PTDC/AAG-MAA/3335/2014; POCI-01-0145-FEDER016778) for financial support through Project 3599 - Promoting the Scientific Production and the Technological Development, and Thematic Networks (3599-PPCDT) - and through FEDER, and the national funds from FCT-Science and Technology Portuguese Foundation for the doctoral grant of D. Blanco-Ward (SFRH/BD/139193/2018). Thanks are also due for the financial support to CESAM (UID/AMB/50017 - POCI-01-0145-FEDER-007638), to FCT/MEC through national funds, and the co-funding by FEDER within the PT2020 Partnership Agreement and Compete 2020.

\section{ORCID}

\section{Daniel Blanco-Ward (10 https://orcid.org/0000-0001-6200- 6051}

Carolina Viceto (1D https://orcid.org/0000-0001-8841-263X

\section{REFERENCES}

Alves, F., Edlmann, M., Costa, J., Costa, P., Macedo, P., Leal Da Costa, P. and Symington, C. (2013). Heat requirements and lenght of phenological stages. Effects of rootstock on red grape varieties at Douro region. 18th International Symposium GIESCO, 7-11 July 2013, Porto, pp. 5.

Anderson, J.D., Jones, G.V., Tait, A., Hall, A. and Trought, M.C.T. (2012) Analysis of viticulture region climate structure and suitability in New Zealand. Journal International des Sciences de la Vigne et du Vin, 46(3), 149-165.

Andrews, T., Gregory, J.M., Webb, M.J. and Taylor, K.E. (2012) Forcing, feedbacks and climate sensitivity in CMIP5 coupled atmosphere-ocean climate models. Geophysical Research Letters, 39(9), 1-7.

Blanco-Ward, D., Queijeiro, J.M.G. and Jones, G.V. (2007) Spatial climate variability and viticulture in the Mino River Valley of Spain Vitis, 46(2), 63-70.

Bonhomme, R. (2000) Bases and limits to using "degree.day" units. European Journal of Agronomy, 13(1), 1-10.

Caetano, M., Nunes, V. and Nunes, A. (2009). Corine land cover 2006 for continental Portugal. Lisboa: Relatorio técnico, Instituto Geográfico Portugués.

Carbonneau, A., Riou, C., Guyon, D., Riom, J. and Schneider, C. (1992). Agrometeorologie de la vigne en France. Luxembourg: L'Office des Publications de l'Union Européenne.
Climaco, P., Ricardo-da-Silva, J., Laureano, O. and Tonietto, J. (2012) O clima vitícola das principais regiões produtoras de uvas para vinho de Portugal. In: Tonietto, J. , Sotés Ruiz, V. and GómezMigues, V. (Eds.) Clima, zonificación, y tipicidad del vino en regiones vitivinícolas Iberoamericanas. Madrid: Programa Iberoamericano de Ciencia y Tecnología para el Desarrollo (CYTED), pp. 315-357.

Corte-Real, A. (2014) Analyzing the influence of the Douro valley weather on the quality and yield of vintage Port. $\mathrm{PhD}$ thesis dissertation, Porto: University of Porto.

Corte-Real, A., Borges, J., Cabral, J.S. and Jones, G.V. (2015) Partitioning the grapevine growing season in the Douro Valley of Portugal: accumulated heat better than calendar dates. International Journal of Biometeorology, 59(8), 1045-1059.

Corte-Real, A., Borges, J., Cabral, J.S. and Jones, G.V. (2016) A climatology of Vintage Port quality. International Journal of Climatology, 37, 3798-3809.

Dee, D.P., Uppala, S.M., Simmons, A.J., Berrisford, P., Poli, P., Kobayashi, S., Andrae, U., Balmaseda, M.A., Balsamo, G., Bauer, P., Bechtold, P., M Beljaars, A.C., van de Berg, L., Bidlot, J., Bormann, N., Delsol, C., Dragani, R., Fuentes, M., Geer, A.J., Haimberger, L., Healy, S.B., Hersbach, H., olm, E.V., Isaksen, L., Kållberg, P., Köhler, M., Matricardi, M., McNally, A. P., Monge-Sanz, B.M., Morcrette, J., Park, B., Peubey, C., de Rosnay, P., Tavolato, C., Thépaut, J., Vitart, F., Acm, B., de Berg van, L., J-j, M., B-k, P. and Rosnay de, P. (2011) The ERA-interim reanalysis: configuration and performance of the data assimilation system. Quarterly Journal of the Royal Meteorological Society, 137, 553-597.

Falloon, P. and Betts, R. (2009) Climate impacts on European agriculture and water management in the context of adaptation and mitigation-The importance of an integrated approach. Science of the Total Environment, 408(23), 5667-5687.

Fraga, H., García de Cortázar Atauri, I., Malheiro, A.C., MoutinhoPereira, J. and Santos, J.A. (2017) Viticulture in Portugal: a review of recent trends and climate change projections. OENO One, 51(2), $61-69$.

Fraga, H., Garcia de Cortazar Atauri, I., Malheiro, A.C. and Santos, J. A. (2016) Modelling climate change impacts on viticultural yield, phenology and stress conditions in Europe. Global Change Biology, 22(11), 3774-3788.

Fraga, H., Malheiro, A.C., Moutinho-Pereira, J., Jones, G.V., Alves, F., Pinto, J.G. and Santos, J.A. (2014) Very high resolution bioclimatic zoning of Portuguese wine regions: present and future scenarios. Regional Environmental Change, 14(1), 295-306.

Fraga, H., Pinto, J.G. and Santos, J.A. (2019) Climate change projections for chilling and heat forcing conditions in European vineyards and olive orchards: a multi-model assessment. Climatic Change, 152, 179-193.

Fraga, H. and Santos, J.A. (2017) Daily prediction of seasonal grapevine production in the Douro wine region based on favourable meteorological conditions. Australian Journal of Grape and Wine Research, 23, 1-9.

Giorgetta, M.A., Jungclaus, J.H., Reick, C.H., Legutke, S., Bader, J., Böttinger, M., Brovkin, V., Crueger, T., Esch, M., Fieg, K., Glushak, K., Gayler, V., Haak, H., Hollweg, H.-D., Ilyina, T., Kinne, S., Kornblueh, L., Matei, D., Mauritsen, T., Mikolajewicz, U., Mueller, W., Notz, D., Pithan, F., Raddatz, T., Rast, S., Redler, R., Roeckner, E., Schmidt, H., Schnur, R., 
Segschneider, J., Six, K.D., Stockhause, M., Timmreck, C., Wegner, J., Widmann, H., Wieners, K.-H., Claussen, M., Marotzke, J. and Stevens, B. (2013) Climate and carbon cycle changes from 1850 to 2100 in MPI-ESM simulations for the coupled model intercomparison project phase 5. Journal of Advances in Modeling Earth Systems, 5(3), 572-597.

Hannah, L., Roehrdanz, P.R., Ikegami, M., Shepard, A.V., Shaw, M. R., Tabor, G., Zhi, L., Marquet, P.A. and Hijmans, R.J. (2013) Climate change, wine, and conservation. Proceedings of the National Academy of Sciences of the United States of America, 110(17), 6907-6912.

Hargreaves, G.H., Asce, F. and Allen, R.G. (2003) History and evaluation of Hargreaves evapotranspiration equation. Journal of Irrigation and Drainage Engineering., 129(1), 53-63.

Haylock, M.R., Hofstra, N., Klein Tank, A.M.G., Klok, E.J., Jones, P. D. and New, M. (2008) A European daily high-resolution gridded data set of surface temperature and precipitation for 1950-2006. Journal of Geophyssical Research: Atmospheres, 113, D20119.

Hidalgo, L. (1980) Caracterización macrofísica del ecosistema medioplanta en los viñedos españoles. Comunicaciones INIA. Serie Producción vegetal, 29, 5-255.

Huglin, P. (1986) Biologie et Ecologie de la Vigne. Lausanne, Paris: Payot.

IPCC (International Panel on Climate Change). (2013) Summary for Policymakers. In: Stocker,T.F., D. Qin, G.-K. Plattner, M. Tignor, S.K. Allen, J. Boschung, A. Nauels, Y. Xia, V. Bex and P.M. Midgley (Eds.) Climate Change 2013: The Physical Science Basis. Contribution of Working Group I to the Fifth Assessment Report of the Intergovernmental Panel on Climate Change. Cambridge, United Kingdom and New York, NY: Cambridge University Press, pp. 3-29.

IPCC (International Panel on Climate Change). (2014) Chapter 4 Terrestrial and Inland Water Systems. In: Field, C.B., V.R. Barros, D.J. Dokken, K.J. Mach, M.D. Mastrandrea, T.E. Bilir, M. Chatterjee, K.L. Ebi, Y.O. Estrada, R.C. Genova, B. Girma, E.S. Kissel, A.N. Levy, S. MacCracken, P.R. Mastrandrea, and White, L.L. (Eds.) Climate Change 2014: Impacts, Adaptation, and Vulnerability. Part A: Global and Sectoral Aspects. Contribution of Working Group II to the Fifth Assessment Report of the Intergovernmental Panel on Climate Change. Cambridge, United Kingdom and New York, NY: Cambridge University Press, pp. 271-359.

IPPC (International Panel on climate Change). (2008) Towards new scenarios for analysis of emissions, climate change, impacts and response strategies. IPPC expert meeting report. Geneva: IPCC.

IVDP (Instituto dos Vinhos do Douro e Porto). (2017a) Areas Dedicated to Grapevine Cultivation. Statistics for the Year 2016. Peso da Régua: IVDP.

IVDP (Instituto dos Vinhos do Douro e Porto). (2017b) Wine production. Statistics for the 2016 year. Peso da Régua: IVDP.

Jones, G. (2013) Uma Avaliação do Clima para a Região Demarcada do Douro: Uma análise das condições climáticas do passado, presente e futuro para a produção de vinho. Vila Real: Association for the Development of Viticulture in the Douro Region (ADVID).

Jones, G.V. and Alves, F. (2012) Impact of climate change on wine production: a global overview and regional assessment in the Douro Valley of Portugal. International Journal of Global Warming, 4 (3/4), 383-406.
Jones, G.V., Andrew, D.A., Hall, A. and Myers, J.W. (2010) Spatial analysis of climate in Winegrape growing regions in the Western United States. American Journal of Enology and Viticulture, 61(3), 313-326.

Jones, G.V., White, M.A., Cooper, O.R. and Storchmann, K. (2005) Climate change and global wine quality. Climatic Change, 73(3), 319-343.

Lopes, J., Eiras-Dias, J.E., Abreu, F., Clímaco, P., Cunha, J.P. and Silvestre, J. (2008) Exigências térmicas, duração e precocidade de estados fenológicos de castas da colecção ampelográfica nacional. Cieência Técnica Vitivinícola, 23(1), 61-71.

Lorenzo, M.N., Taboada, J.J., Lorenzo, J.F. and Ramos, A.M. (2012) Influence of climate on grape production and wine quality in the Rías Baixas, North-Western Spain. Regional Environmental Change, 13(4), 887-896.

Malheiro, A., Santos, J., Fraga, H. and Pinto, J. (2010) Climate change scenarios applied to viticultural zoning in Europe. Climate research, 43, 163-177.

Marta-Almeida, M., Teixeira, J., Carvalho, M.J., Melo-Gonçalves, P. and Rocha, A.M. (2016) High resolution WRF climatic simulations for the Iberian Peninsula: model validation. Physics and Chemistry of the Earth, 94, 94-105.

Mcmaster, G.S. and Wilhelm, W.W. (1997) Growing degree-days: one equation, two interpretations. Agricultural and Forest Meteorology, 87(4), 291-300.

Mira de Orduña, R. (2010) Climate change associated effects on grape and wine quality and production. Food Research International, 43, 1844-1855.

Moriondo, M., Jones, G.V., Bois, B., Dibari, C., Ferrise, R., Trombi, G. and Bindi, M. (2013) Projected shifts of wine regions in response to climate change. Climatic Change, 119(3-4), 825-839.

Pereira, S.C., Marta-Almeida, M., Carvalho, A.C. and Rocha, A. (2017) Heat wave and cold spell changes in Iberia for a future climate scenario. International Journal of Climatology, 37, 5192-5205.

Pons, A., Allamy, L., Schüttler, A., Rauhut, D., Thibon, C., Darriet, P. and Ollat, N. (2017) What is the expected impact of climate change on wine aroma compounds and their precursors in grape? Journal International des Sciences de la Vigne et du Vin, 51(2), 141-146.

Riahi, K., Rao, S., Krey, V., Cho, C., Chirkov, V., Fischer, G., Kindermann, G., Nakicenovic, N. and Rafaj, P. (2011) RCP 8.5-a scenario of comparatively high greenhouse gas emissions. Climatic Change, 109(1-2), 33-57.

Riou, C. (1994) Le determinisme climatique de la maturation du raisin: application au zonage de la teneur en sucre dans la Communaute Europeenne. Luxembourg: L'Office des Publications de l'Union Européene.

Santos, J.A., Grätsch, S.D., Karremann, M.K., Jones, G.V. and Pinto, J. G. (2013) Ensemble projections for wine production in the Douro Valley of Portugal. Climatic Change, 117(1-2), 211-225.

Santos, J.A., Malheiro, A.C., Karremann, M.K. and Pinto, J.G. (2011) Statistical modelling of grapevine yield in the port wine region under present and future climate conditions. International Journal of Biometeorology, 55, 119-131.

Santos, J.A., Ricardo, C. and Helder, F. (2018) New insights into thermal growing conditions of Portuguese grapevine varieties under changing climates. Theoretical and Applied Climatology, 135, 1215-1226. 
Sillmann, J., Kharin, V.V., Zhang, X., Zwiers, F.W. and Bronaugh, D. (2013a) Climate extremes indices in the CMIP5 multimodel ensemble: part 1. Model evaluation in the present climate. Journal of Geophysical Research Atmospheres, 118(4), 1716-1733.

Sillmann, J., Kharin, V.V., Zwiers, F.W., Zhang, X. and Bronaugh, D. (2013b) Climate extremes indices in the CMIP5 multimodel ensemble: part 2. Future climate projections. Journal of Geophysical Research Atmospheres, 118(6), 2473-2493.

Skamarock, W.C., Klemp, J.B., Dudhi, J., Gill, D.O., Barker, D.M., Duda, M.G., Huang, X.-Y., Wang, W. and Powers, J.G. (2008). A description of the advanced research WRF version 3. Boulder, CO: National Center for Atmospheric Research (NACR) technical note.

Teixeira, A., Eiras-Dias, J., Castellarin, S.D. and Gerós, H. (2013) Berry phenolics of grapevine under challenging environments. International Journal of Molecular Sciences, 14(9), 18711-18739.

Tonietto, J. and Carbonneau, A. (2004) A multicriteria climatic classification system for grape-growing regions worldwide. Agricultural and Forest Meteorology, 124, 81-97.

van der Linden, P. and Mitchell, J.F.B. (2009) ENSEMBLES: Climate Change and its Impacts: Summary of Research and Results from the ENSEMBLES Project. Exeter: Met Office Hadley Centre.

van Leeuwen, C. and Darriet, P. (2016) The impact of climate change on viticulture and wine quality. Journal of Wine Economics, 11(1), $150-167$.

van Leeuwen, C., Schultz, H.R., Garcia de Cortazar-Atauri, I., Duchene, E., Ollat, N., Pieri, P., Bois, B., Goutouly, J.-P.,
Quenol, H., Touzard, J.-M., Malheiro, A.C., Bavaresco, L. and Delrot, S. (2013) Why climate change will not dramatically decrease viticultural suitability in main wine-producing areas by 2050. Proceedings of the National Academy of Sciences, 110(33), E3051-E3052.

Viceto, C., Marta-Almeida, M. and Rocha, A. (2017) Future climate change of stability indices for the Iberian Peninsula. International Journal of Climatology, 37, 4390-4408.

Winkler, A., Cook, J., Kliiewer, W. and Lider, L. (1974) General Viticulture. Berkely, CA: University of California Press.

\section{SUPPORTING INFORMATION}

Additional supporting information may be found online in the Supporting Information section at the end of this article.

How to cite this article: Blanco-Ward D, Monteiro A, Lopes M, et al. Climate change impact on a wine-producing region using a dynamical downscaling approach: Climate parameters, bioclimatic indices and extreme indices. Int $J$ Climatol. 2019;1-20. https://doi.org/10.1002/joc.6185 